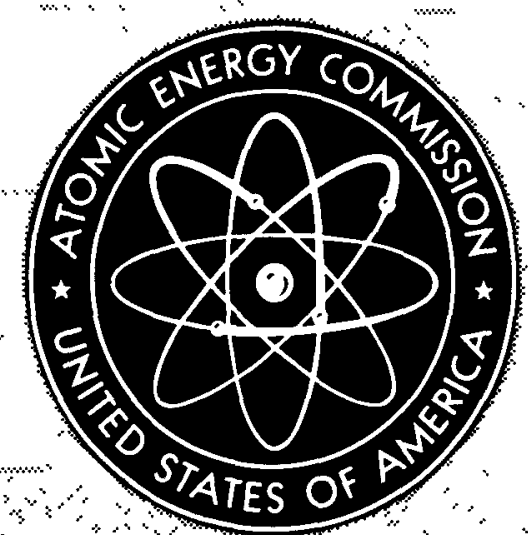

MND-P-2335

PHYSICS AND MATHEMATICS

\title{
INTERIM REPORT ON SAFETY PROCEDURES FOR THE TASK 2 THERMOELECTRIC GENERATOR
}

By

L. T. Kleln

March 15, 1960

Nuclear Division

Martin Company

Baltimore, Maryland 


\section{DISCLAIMER}

This report was prepared as an account of work sponsored by an agency of the United States Government. Neither the United States Government nor any agency Thereof, nor any of their employees, makes any warranty, express or implied, or assumes any legal liability or responsibility for the accuracy, completeness, or usefulness of any information, apparatus, product, or process disclosed, or represents that its use would not infringe privately owned rights. Reference herein to any specific commercial product, process, or service by trade name, trademark, manufacturer, or otherwise does not necessarily constitute or imply its endorsement, recommendation, or favoring by the United States Government or any agency thereof. The views and opinions of authors expressed herein do not necessarily state or reflect those of the United States Government or any agency thereof. 


\section{DISCLAIMER}

Portions of this document may be illegible in electronic image products. Images are produced from the best available original document. 


\section{LEGAL NOTICE}

This report was prepared as an account of Government sponsored work. Nelther the United states, nor the Commission, nor any person acting on behalf of the Commission:

A. Makes any warranty or representation, expressed or implied, with respect to the accuracy, completeness, or usefulness of the information contained in this report, or that the use of any information, apparatus, method, or process disclosed in this report may not infringe privately owned rights; or

B. Asaumes any liabilities with respect to the use of, or for damages resulting from the use of any information, apparatus, method, or process disclosed in this report.

As used in the above, "person acting on behalf of the Commisston" includes any employee or contractor of the Commission, or employee of such contractor, to the extent that such employee or contractor of the Commission, or employee of such contractor prepares, diseeminates, or provides access to, any information pursuant to hls employment or contract with the Commission, or his employment with such contractor.

This report has been reproduced directly from the best avallable copy.

Printed in USA. Price $\$ 1.50$. Avallable from the Office of Technical Services, Department of Commerce, Washington 25, D. C. 
MND-P-2335

\section{INTERIM REPORT ON SAFETY PROCEDURES \\ FOR THE}

\section{TASK 2 THERMOELECTRIC GENERATOR}

\section{MARCH 15, 1960}

Prepared by: L. T. Klein

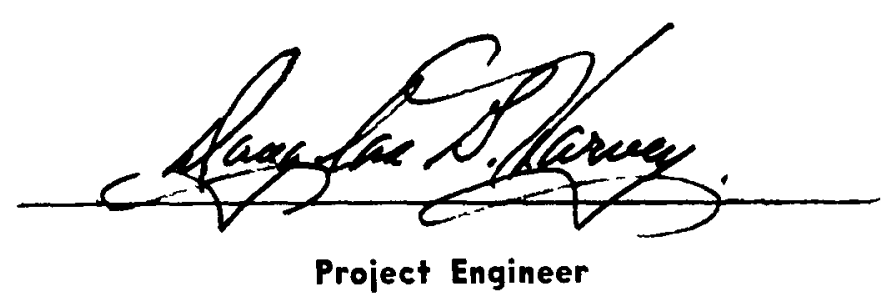

Nuclear Division

Martin Company

Baltimore, Maryland 
page blank 


\section{FOREWORD}

This report describes the preliminary evaluation of hazards and handling procedures associated with the use of the SNAP IA thermoelectric generator in a satellite mission. The report was prepared under Contract AT(30-3)217 with the AEC. 
page blank

vi 
Page

Foreword $\ldots \ldots \ldots \ldots \ldots \ldots \ldots \ldots \ldots \ldots \ldots \ldots$

Summary ..................... ix

I. Introduction. ................... 1

II. Description of Task 2 Thermoelectric Generator....... 3

A. Generator Design ................. 3

B. Fuel Capsule .................. 5

C. Nuclear Properties of the Fuel ............ 5

D. Biological Hazards ................. 9

III. Transportation. .................. 11

A. Major Equipment. ................ 11

B. Preparation for Shipment ............. 13

C. Shipment ...................... 15

IV. Ground Handling. .................. 19

A. Auxiliary Support Equipment . . . . . . . . . 19

B. Modification or Addition to Existing Equipment. ..... 21

C. Integ ration of Generators and Typical Missile ..... 23

D. Procedures ..................... 27 
vi11

CONTENTS (continued)

Page

v. Aborted Flight Procedures. . . . . . . . . . . 37

A. Abort Classification. . . . . . . . . . . 37

B. Search and Recovery . . . . . . . . . . . . . 40

Bibliography . . . . . . . . . . . . . . . . 49

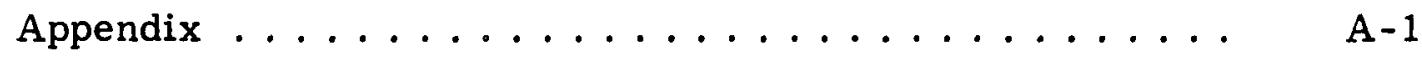




\section{SUMMARY}

This report evaluates the operational hazards associated with the use of a radioisotope-fueled auxiliary power unit for a satellite mission. The entire factory-to-flight and/or retrieval and disposal sequence is examined, and safe handling procedures suggested.

Each Task 2 generator initially produces 6500 thermal watts from radioactive beta decay, a portion of which is converted via thermoelectric elements to 125 electrical watts. A thermal shutter is used to furnish a controlled heat loss (and provide a constant power level over the design life of one year). The initial fuel load of the generator is 0.88 megacuries of Cerium-144 which has a half-life of 285 days.

The configuration of the generator is that of a 24 inch diameter cylinder with hemispherical ends. Overall length is 34.1 inches. A biological shield consisting of 4000 pounds of mercury fills the internal volume of the generator during prelaunch handling and is drained immediately prior to launch. The unit weighs approximately 200 pounds during operation and 4200 pounds with the mercury shield in place during prelaunch preparations.

A cylindrical 7-hole Inconel-X fuel capsule, $41 / 4$ inches in diameter and 11 inches in length, contains the radiocerium fuel pellets in the form of ceric oxide.

The biological hazards associated with the generator are direct radiation from the fuel, internal radiation dose if the fuel is released to the biosphere in a form in which the body may assimilate, and the dangers inherent in the use of mercury for shielding purposes with the possible presence of mercury vapor in the air around the generator.

The ceric oxide fuel would be prepared and encapsulated at Oak Ridge National Laboratory and shipped by rail to the launch site, Vandenberg AFB near Santa Maria, California. A 12,500-pound lead shipping cask would be used to provide shielding of the fuel, adequate cooling of the fuel core, and containment of the fuel during credible transport accidents. Tests have shown that forces greater than those available from the maximum credible rail accident are required to breach the fuel core and release the fuel.

At the launch site the fuel core would be mated to the generator. The shipping cask, generator and auxiliary support equipment are designed to facilitate the handling and loading of the fuel core into the generator, and mating of the generator to the satellite vehicle without a hot cell. 
When mated with the satellite vehicle the two generators are located on opposite sides of the vehicle next to the final stage rocket exhaust nozzle. The generators are placed so as to not interfere with the operating portions of the vehicle. When the satellite vehicle is mated with the booster and the mercury shield drained, the generators are approximately 1000 feet from the nearest personnel located in the shielded launch operations building. Exposed personnel at this distance would receive a dose of approximately $0.6 \mathrm{r} / \mathrm{hr}$ from the two unshielded generators. If the launch is scrubbed at the last minute, the mercury could be returned to the generator to facilitate work in and around the vehicle.

After a violent prelaunch abort or an abort ending in impact on land adjacent to the launch site, remotely controlled vehicles would be used to recover the radioactive fuel cores without exposing the operating personnel to dangerous radiation levels. If the fuel core impacts in the relatively shallow water areas adjacent to the launch site, it would be possible to recover the fuel cores. Tests have shown that the fuel cores would not be deformed as a result of launch aborts, and recovery of the cores for reuse or safe disposal would be possible. 


\section{INTRODUCTION}

This report has been prepared for the U.S. Atomic Energy Commission to evaluate the operational procedures for the Task 2, 125-watt generator with respect to possible physical and radiological hazards. It was assumed that the generator was to be used as an Auxiliary Power Unit (APU) in a typical satellite mission.

A system has been devised for the handling, transportation and transfer of the Task 2 thermoelectric generator. The first phase of the operation will be accomplished at Oak Ridge National Laboratory, where an Inconel-X fuel core will be remotely loaded with the radiocerium fuel and sealed. A specially designed cask will be used to ship the fuel block to a launch site where the fuel core will be transferred to the generator. During all handling operations, the fueled generator will be filled with 4000 pounds of mercury which will serve as a biological shield. The generator will then be mated to a satellite vehicle, which will be placed atop the booster rocket. In the course of a normal prelaunch countdown at $T=-300$ seconds, the shield will be drained from the unit. In the event of a hold in the countdown or a prelaunch scrub, the shield may be pumped back into the unit to allow personnel to work in and around the vehicle or to remove the unit from the satellite. In the event of a launch pad abort or an early stage flight abort, where impact on the launch site is possible, procedures are available for the recovery and disposal of the Auxiliary Power Unit. 
page blank 


\section{DESCRIPTION OF TASK 2 THERMOELECTRIC GENERATOR}

Two Task 2 thermoelectric generators could be utilized to power certain electrical equipment in a satellite system requiring a maximum of 250 watts. Each generator supplies 125 electrical watts, 28 volts dc at 4.46 amperes, into a matched impedance load for a period of one year. A single generator initially produces 6500 thermal watts from the decay heat of the radioisotope fuel- $-880,000$ curies of Cerium144. Heat is produced by beta particles, resulting from the decay of $\mathrm{Ce}-144^{\mathrm{B}^{-}} \mathrm{Pr}-144^{\mathrm{B}^{-}} \mathrm{Nd}-144$, slowing down and giving up their energy to the fuel element material. The fuel, in turn, radiates its heat to the fuel core. To provide a constant power level, 4000 watts of the initial output are radiated to the environment by means of a thermal shutter. During the one-year life span, the thermal shutter is gradually closed to compensate for radioisotope decay.

\section{A. GENERATOR DESIGN}

As shown in Fig. 1, the generator is made up of a structurally supported fuel core and an outer shell. Its outer configuration is that of a cylinder with hemispherical ends, 34.1 inches in overall length and 24.0 inches in diameter. The shell of the unit, which contains the thermoelectric elements, is made up of two integral skins. An inner skin of stainless steel serves as the thermoelement hot junction, and an outer skin of aluminum as the cold junction. A thermal insulating material is packed around the elements between the two skins.

The insulation located at the bottom of the unit is hinged and is opened by a mechanism to permit a portion of the inner skin to radiate heat to a cold sink. This keeps the hot junction temperature constant, thereby regulating the power output of the device.

An internal shield for directing thermal radiation toward the shutter area has been added to the design of the generator to provide adequate dumping of excess isotopic heat. This radiant heat shield is made up of two layers of stainless steel sheet shaped in the form of a frustum of a right cone. The cone is installed in the annular space between the fuel core support housing and the inner skin. The large open end of the cone will expose the shutter area to direct thermal radiation and high intensity reradiation from the fuel core while shielding the thermoelectric areas of the generator. 


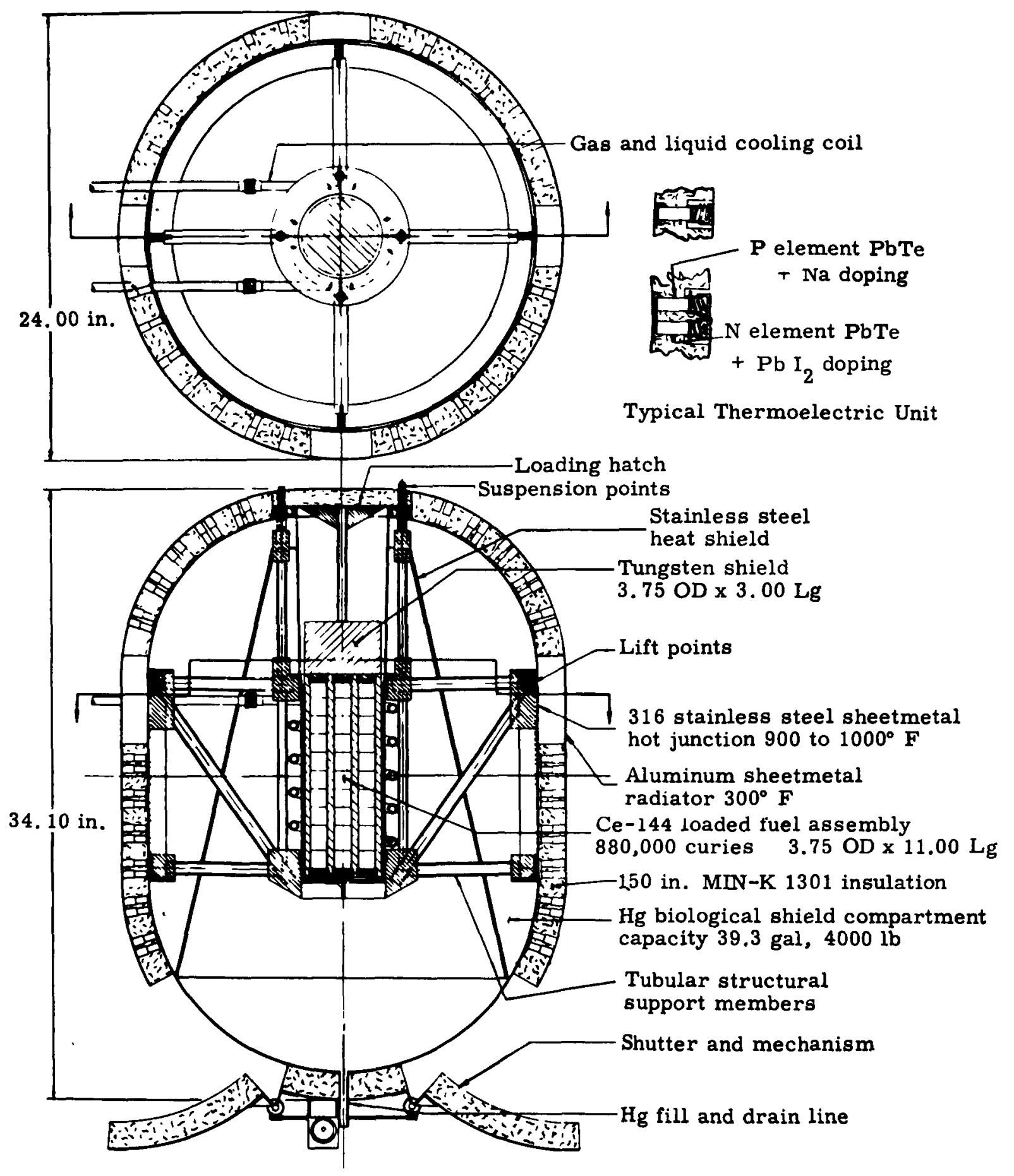

F1g. 1. Thermolectric Generator 
Heat is generated by a loading of 880,000 curies of $\mathrm{Ce}-144$ contained in an Inconel-X block at the center. The block is supported from the shell by tubular truss members which, in turn, are suspended by tension members passing through the top of the unit. The tension members are attached to the flight vehicle structure.

A tungsten block 3.75 inches in diameter and 3.0 inches long is located over the fuel block assembly to provide in-flight shielding. Ground shielding is provided by completely filling the interior of the unit with approximately 4000 pounds of mercury. Just prior to launching, this mercury is drained. A coil surrounding the isotope block serves to carry coolant for the shield mercury.

\section{B. FUEL CAPSULE}

The fuel capsule will be a cylindrical Inconel-X metal block, 11 inches long and 4-1/4 inches in diameter with seven equally spaced holes drilled through the block parallel to its axis. A 0.49 -inch thick threaded cap is fitted to the top and bottom of each hole and welded closed. Discussions with ORNL personnel resulted in a decision to load the radiocerium fuel pellets into thin-walled stainless steel tubes prior to installation in the fuel capsule. In this manner, fuel loading operations and core surface contamination would be minimized. Each fuel tube will contain 0.1257 megacuries of $\mathrm{Ce}-144$. Figure 2 shows this configuration.

\section{NUCLEAR PROPERTIES OF THE FUEL}

Cerium-144 is a fission product which is separated from reactor wastes. The decay of Cerium-144 to its daughter, Praseodymium-144, results in the emission of beta particles and gamma rays, but most of the thermal power is derived from the energetic beta decay of Praseodymium-144 to Neodymium-144. Thus, in addition to the decay gamma radiation emitted by radiocerium, a large portion of the photon radiation emitted is in the form of $\mathrm{X}$-radiation originating from the slowing down of energetic beta decay particles (Bremsstrahlung). Table 1 lists the nuclear properties of Cerium-144 and its daughter. Figure 3 shows the decay scheme of Cerium-144. 


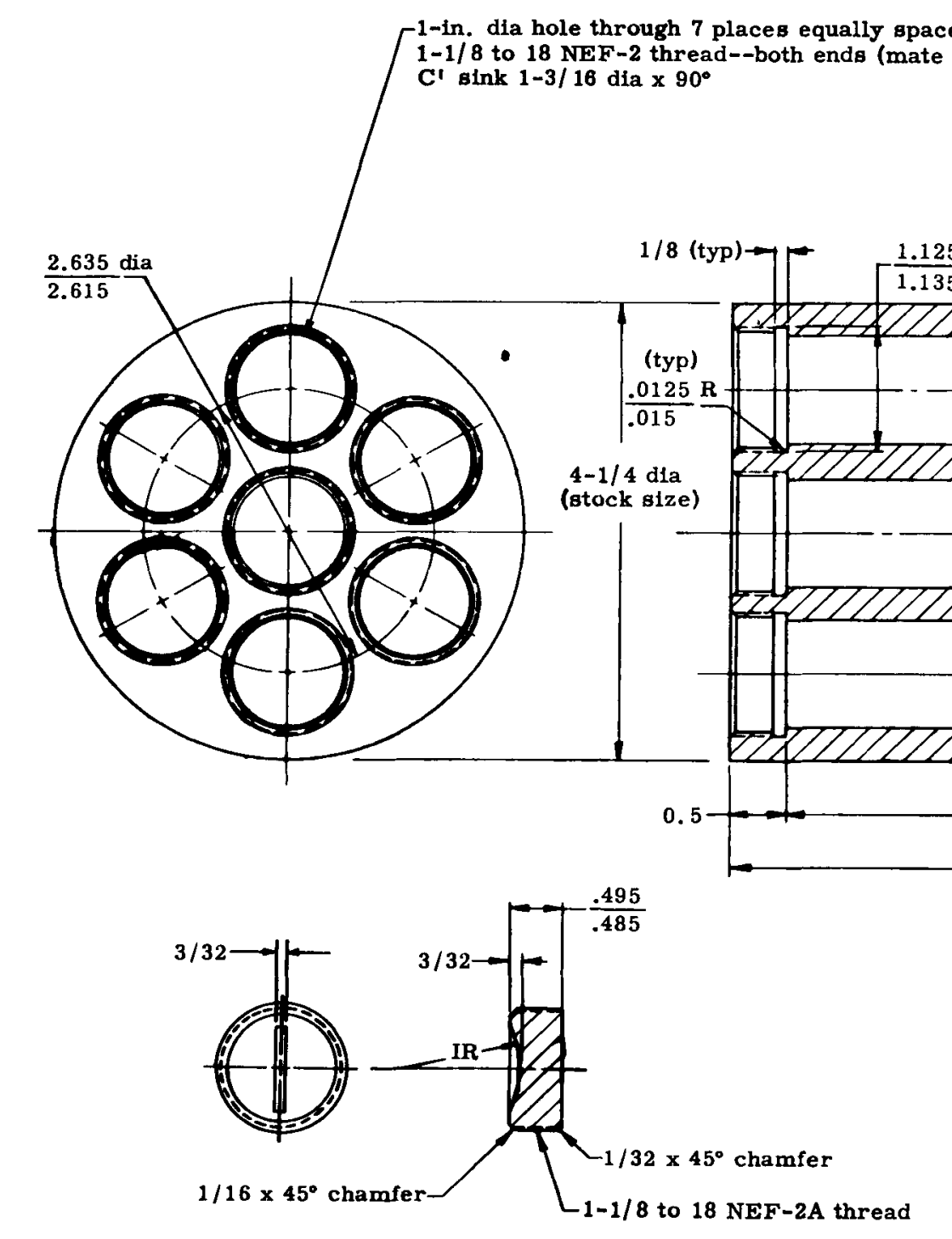

Detall-1

NOTE:

1. Break all sharp edges 0.010 minimum

2. Ink stamp part identification. 


\section{TABLE 1}

Radionuclide

Ce-144

$\underline{\operatorname{Pr}-144}$

Nd-144

Half life

285 days

$17.5 \mathrm{~min}$

$5 \times 10^{15}$ year

Mode of decay:

$B$ -

B-

$\alpha$

Specific activity

$3.2 \times 10^{3}$

$7.5 \times 10^{7}$

$4.9 \times 10^{-13}$

Curies/gm*

Energy of decay

$B_{1} \quad 0.327$

${ }^{B} \mathrm{x} 3.01$

1.9

particles (mev)

$\begin{array}{lllll}\beta_{2} & 0.258 & B_{y} & 2.30 \\ \beta_{3} & 0.16 & B_{z} & 0.79\end{array}$

Abundance (\%)

$$
\begin{array}{ll}
B_{1} 75.0 & B_{x} 98 \\
B_{2} \sim 5.0 & B_{y} \sim 1.3 \\
B_{3} \sim 20.0 & B_{z} \sim 1.0
\end{array}
$$

Gamma energ

$\begin{array}{llll}\gamma_{1} & 0.054 & \gamma_{x} & 0.69 \\ \gamma_{2} & 0.080 & \gamma_{y} & 1.50 \\ \gamma_{3} & 0.134 & \gamma_{z} & 2.18\end{array}$

Relative abundance $(\%)$

$$
\begin{array}{llll}
\gamma_{1} & 3.0(10 \%) & \gamma_{x} & 1.6 \\
\gamma_{2} & 3.0(10 \%) & \gamma_{y} & 0.25 \\
\gamma_{3} & 7.5(15 \%) & \gamma_{z} & 0.8
\end{array}
$$

Other radiation

$$
\begin{array}{ll}
x \text { from } & x \text { from } \\
\text { Bremsstrah- } & \text { Bremsstrah- } \\
\text { lung } & \text { lung }
\end{array}
$$

* Pure isotope with 0 decay。 


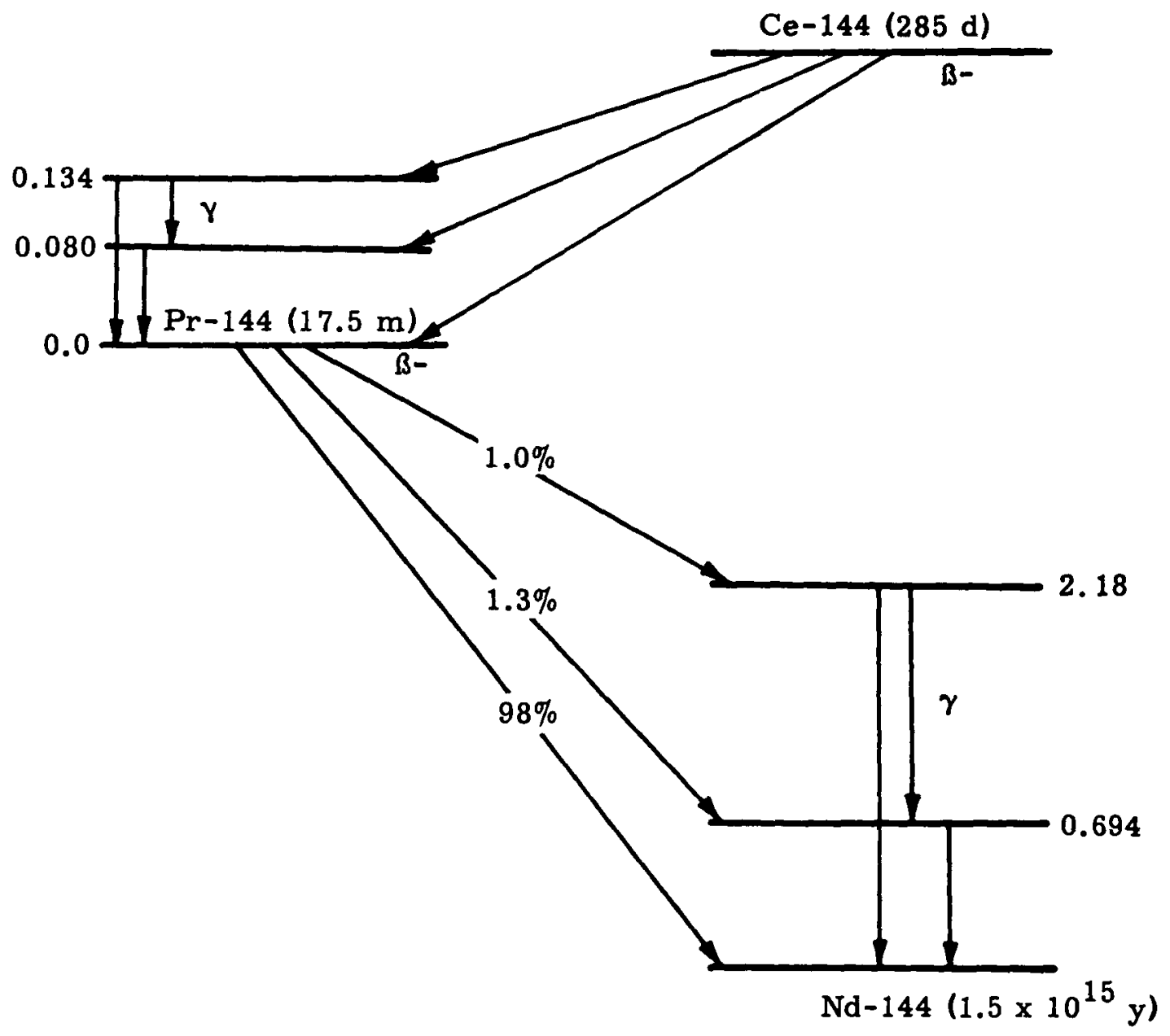

F1g. 3. Decay Scheme of Cerlum-144 


\section{BIOLOGICAL HAZARDS}

In addition to the danger from direct radiation, Cerium-144 represents a radiobiological hazard if released to the biosphere in a form which the body may assimilate through ingestion or respiration.

The Task 2 generator is designed to minimize the chance of radionuclide intake by the body by means of absolute containment and the use of insoluble fuel form $\left(\mathrm{CeO}_{2}\right)$. The use of mercury for shielding purposes is necessary in the factory-to-flight sequence of the Task 2 generator. Mercury vapor is a serious hazard which should not be overlooked. Air concentrations as low as 0.1 milligram of mercury per cubic meter of air are dangerous. ${ }^{1}$ Personnel working in such an atmosphere must wear protective respiratory equipment。

The following data are the International Committee on Radiation Protection (ICRP) recommendations on the maximum permissible body burdens and maximum permissible concentrations (MPC) of radionuclides in air and water for occupational exposure.* A maximum of 5 microcuries of Cerium-144 is the whole body burden permitted, with the bone being the critical organ. The maximum permissible concentration in air is $10^{-8}$ microcurie, per cubic centimeter. Since the fuel form for the Task 2 generator is insoluble, different limits apply. For insoluble forms of cerium, the MPC in water is $3 \mathbf{x}$ $10^{-4}$ microcurie per cubic centimeter. Following ingestion, the radionuclide is expected to pass through the body without appreciable absorption and to be eliminated with a retention half life of 1500 days. In this case, the gastrointestinal tract, more specifically, the lower large intestine, is the critical organ.

The lungs are the critical organs for inhalation of the isotope. As shown below, it can be assumed that the gastrointestinal tract would also be seriously exposed. Retention of particulate matter in the lungs depends on many factors, such as size, shape and density of the particles. Lacking specific data, however, the International Commission on Radiological Protection assumes the following distribution:

1 Sax, N. I., "Dangerous Properties of Industrial Materials," Reinhold, N.Y.. 1957 .

* Personal Communication with $\mathrm{K}$ 。Z. Morgan, Member of ICRP. 
Distribution of Inhaled Particulate Matter

Exhaled

$25 \%$

Deposited in upper respiratory passages and subsequently swallowed $50 \%$

Deposited in the lungs

$25 \% *$

* Of this, half is eliminated from the lungs and swallowed in the first 24 hours making a total of $62-1 / 2 \%$ swallowed. 


\section{TRANSPORTATION}

Shipment of the APU to the launch site is divided into two specific operations: (1) shipment of nonradioactive hardware, such as empty generators, field handling equipment, and auxiliary components, and (2) shipment of the radioisotope-loaded fuel cores. Shipment of nonradioactive hardware from Baltimore to the launch site is governed by conventional shipping procedures and does not warrant further discussion. Point of origin for the fuel core shipment will be Oak Ridge National Laboratory (ORNL) located near Knoxville, Tennessee, and the destination will be Vandenberg AFB near Santa Maria, California. The fuel cores and the generator components will be assembled at the launch site as described in Chapter IV.

The following discussion includes a description of the major equip ment involved in the handling and transportation of the core, the mode of shipment, an outline of the procedures used for preshipment operations, and a general examination of the shipment itself.

\section{A. MAJOR EQUIPMENT}

\section{Shipping Cask}

A shipping cask for each fuel core is designed to provide shielding of the fuel, adequate cooling of the fuel core, and containment of the core during credible transport accidents. Figure 4 is a view of the shipping cask.

Shielding. The shipping cask is designed for a dose rate of 10 milliroentgens/hour or less at three feet from the surface when loaded with

$8.8 \times 10^{5}$ curies of Cerium-144. This is achieved by using a 13 -inch thickness of lead around the fuel core. Dose rates obtained during the field transfer operation from the shipping cask are discussed in the Appendix.

Cooling of the cask. Heat from the isotope-loaded fuel core is transmitted to the inner surface of the cask by means of Wood's metal, a liquid heat transfer medium added to the inner container after loading. This heat is then conducted through the shielding lead to the surface of the cask and dissipated from the surface via cooling fins attached to the cask. Wood's metal, an alloy of bismuth $(50 \%), \mathrm{Pb}(25 \%), \mathrm{Sn}(12.5 \%)$ and $\mathrm{Cd}(12.5 \%)$, melting at $70^{\circ} \mathrm{C}$, is unaffected by radiation and provides a dense fluid path for the transmission of heat from the hot fuel core to the cask. Included in the design of the cask is a cooling coil which is used to reduce the fuel core temperature prior to installing the core in the generator. 


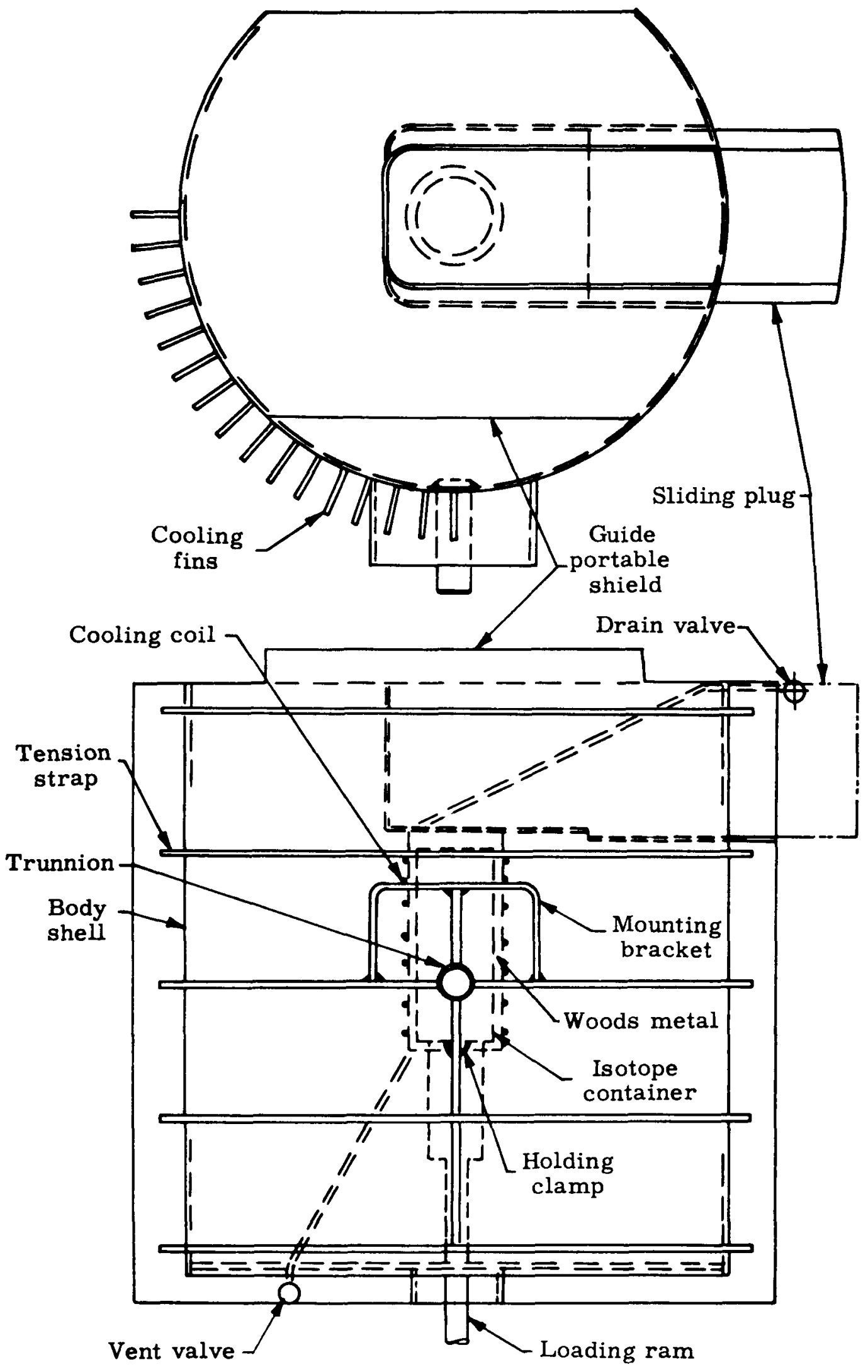

Fig. 4. Shipping Cask 
Cask design and containment. Shielding lead for the cask is encased in a steel shell fitted with cooling fins and supported by tension straps. An inner container in the center of the cask supports the fuel core. The bottom of the cask is fitted with a loading ram and coupling device; the top is fitted with a sliding plug for core loading. During shipment, a steel plate bolted to the cask covers the sliding plug and denies access to the fuel core. The steel plate will be fitted with wired seals which must be broken if the container is tampered with or opened for any purpose. Each cask weighs approximately 13,250 pounds. The function of the cask components are described in later sections of this chapter.

\section{Shipping Skid}

Since the large mass of the cask is concentrated in a relatively small area, a skid approximately 6 feet by 8 feet is provided to distribute the weight onto the floor of the conveying vehicle and permit shipment by rail or truck. Tiedowns designed to withstand an ultimate forward or aft load of $15 \mathrm{~g}$ are provided to secure the cask to the skid. For rail shipment, the skid will probably be blocked to prevent shifting of the load. In the event of blocking at the ends, a forward or aft load of 1-1/2 g would upend the skid. Therefore, in addition to blocking, the skid must be tied down to the floor of the car. Since the vertical component of the $15 \mathrm{-g}$ forward load at the aft end of the skid would be $5 \mathrm{~g}$ or 80,000 pounds ultimate, the skid must be tied down to the conveyance so that the vertical tiedowns have an 80,000-pound ultimate vertical load capacity at each end of the skid. Also, at each end, the blocking must have a $15-\mathrm{g}$ or $240,000-$ pound ultimate load capacity. If blocking is not used, forward and aft loads can be taken by securing to tiedown rings located along the sides of the skid.

\section{Protective Cage and Hoist}

Since the cask dissipates the heat generated by the isotope to the surroundings, its surface temperature will be approximately $270^{\circ} \mathrm{F}$. In order to protect personnel working around the shipment, the shipping cask assembly is surrounded by a protective cage. This was done at the request of the Bureau of Explosives. To obviate the need for special hoisting equipment at the destination, and in the event that the shipment must be removed from the conveyance at some intermediate point during the trip, a hoist assembly has been included in the handling equipment. This permits any crane of suitable capacity to be used for handling the shipping cask assembly。 Figure 5 is an exploded view of the shipping cask assembly。

\section{B. PREPARATION FOR SHIPMENT}

ORNL personnel will load the fuel core (Fig. 2) with the radiocerium fuel and weld the end caps for a positive seal. The surface of the loaded 


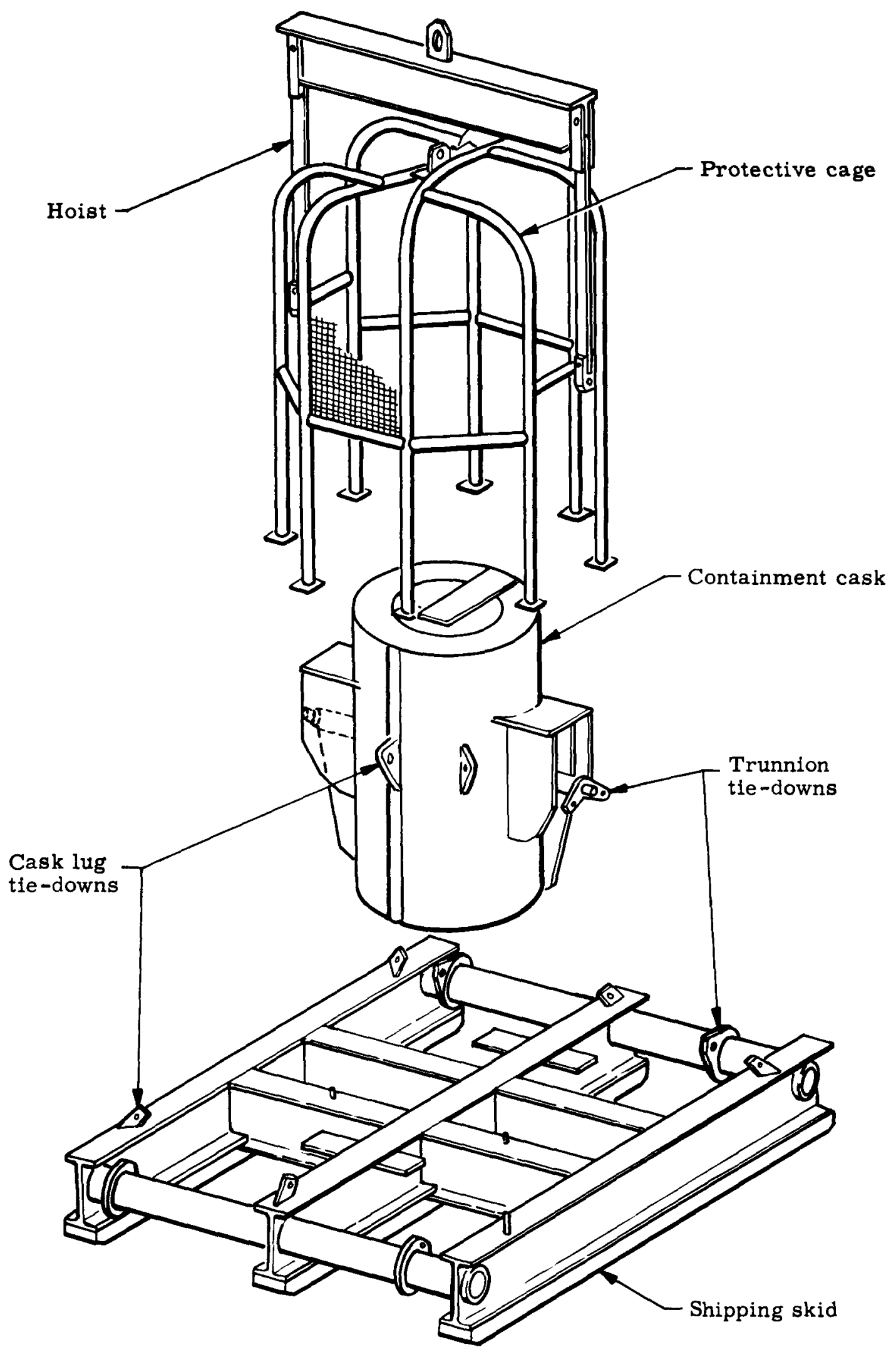

Fig. 5. Exploded View of Shipment 
fuel cores will be decontaminated to prevent contamination of the cask and generator. Remote handling procedures for these operations have been in use at ORNL for some time and require no further examination in this report.

\section{Insertion of Fuel Core Into Cask}

Due to its high radiation field, the core will be loaded into the shipping cask in a hot cell by remote handling techniques (see Appendix).

Prior to the loading of the block, all electrical and air connections will be checked, personnel will evacuate the hot cell, and the hot cell openings will be secured. The Wood's metal will be brought up to temperature $\left(190^{\circ} \mathrm{F}\right.$ minimum) and ali valves and piping checked for proper operation. The core will be placed in the shipping cask with manipulators; a check fixture will be used to ensure positive engagement with the locking mechanism in the shipping cask. Precautions must be taken to avoid damage to the locking mechanism in that the core must not be dropped into the cask. If the core is inadvertently dropped, it must be removed and the locking mechanism checked. Wood's metal will be poured through electrically heated lines into the cavity : srrounding the block until it begins to overflow from the vent line; Wood's metal lines will be closed off and the sliding plug will then be secured. Following satisfactory monitoring and decontamination, the cask will be removed from the hot cell. Care should be taken to check the bottom of the cask for possible Wood's metal leakage, particularly around the point where the block lock shaft penetrates the cask. Loss of the Wood's metal would lower the heat transfer rate between the fuel core and the cask, and the fuel core temperature could increase to a maximum of $1500^{\circ} \mathrm{F}$. If there are indications of a leak that cannot be stopped by tightening the locking device, the cask must be returned to the hot cell and the defective seals replaced. Protective gloves must be worn at all times when working around the cask after the fuel core has been inserted, since temperatures on the surface of the cask are expected to approach $270^{\circ} \mathrm{F}$.

\section{Mating of Cask to Skid}

A 10-ton crane will remove the cask from the hot cell and position it on the skid. A protective cage will then be placed over the cask and bolted to the skid as shown in Fig. 5. The cask will be tied to the skid with six turnbuckles.

\section{SHIPMENT}

The cask will be shipped by rail to the launch site. Due to its weight, the cask must be loaded with a crane. For this reason, the Pennsylvania Railroad has recommended that shipment be made in a gondola car. The open top of the car will allow the shipment to be loaded by the crane with 
minimum difficulty. In the event of failure of the cask or skid, protection to other shipments and containment of the material will be provided by the four steel walls of the car.

"Preferred Rail Handling" will be requested for all shipments involving the cask. The use of "humping" for the making up of trains and dynamic coupling shall be avoided if at all possible. Bureau of Explosives Permit No. 898 has been issued for this shipment. The Bureau of Explosives, New York 7, New York, will be notified of the following items for each shipment:

(1) Point of origin.

(2) Point of destination.

(3) Date of shipment.

(4) Type of transportation used.

(5) Quantity, in curies, of radioactive material being shipped.

\section{Shipping Hazards}

The potential hazards associated with shipping the radiocerium fuel core are: (1) direct external radiation exposure from the fuel and (2) internal radiation exposure from ingestion or inhalation of the fuel in particulate form. Countermeasures inherent in the fuel core-shipping cask design to prevent or minimize exposure are:

(1) Multiple containment.

(2) Biological shielding.

Selection of shipping routes, optimization of shipping procedure, proper location of the cask on the carrier, regulation of shipping time, and utilization of an escort can significantly diminish the frequency and magnitude of transport accidents in which the generator is involved. The cask will be shipped by truck and train to its destination.

Truck. Truck accidents that could be postulated are collision (impact), explosion and fire. Truck movements involved in this shipment, however, are of a type which preclude the possibility of a major accident. The shipment will be moved by truck from the hot cell at ORNL to a railroad siding located within the plant area. At the launch site, the cask shipping skid assembly will be moved by truck from a railway siding located within the launch complex of the Pacific Missile Range to the prelaunch preparation area. 
Rail. Rail shipment will be made from Oak Ridge National Laboratory (ORNL) located near Knoxville, Tennessee, to Vandenberg AFB, near Santa Maria, California. The route is across the relatively sparsely populated southern portion of the U.S. through Tennessee, Arkansas, Oklahoma, Texas, New Mexico, Arizona and Southern California. Where movement through the more densely populated urban centers is required, administrative controls will provide assurance that the train moves through as safely as possible. This will be accomplished by scheduling the shipments on a through train, with a minimum number of stops enroute for the uncoupling or addition of cars.

Rail accidents that could be postulated are collision or derailment, explosions and fire. Table 2 lists some pertinent railroad accident statistics.

\section{TABLE $\quad 2$}

Railroad Accident Statistics ${ }^{2}$

\section{Type of Accident}

All rail freight accidents

Accident involving gasoline fire

Accident involving explosions
Chance of Accident Per 1000-Mile Shipment

$1 / 3,300$

$1 / 22,000$

$1 / 87,000$

Derailments at high speed present the greatest danger to the shipment. Approximately $50 \%$ of the freight car derailments occur at speeds greater than $35 \mathrm{mph}$, and $24 \%$ at speeds greater than $45 \mathrm{mph}$. A freight car leaving the tracks at $80 \mathrm{mph}$ (117 fps) and impacting upon a rigid medium is considered a maximum credible rail accident. In tests conducted by The Martin Company at the Aberdeen Proving Grounds, bare fuel cores at operating temperatures have been impacted upon granite at $500 \mathrm{fps}$ without significant damage. For this reason and because the core receives additional protection from the shipping cask it is expected that the maximum credible rail accident would not result in a release of the radioisotope fuel.

${ }^{2}$ Knapp, Harold A., et al., "Cost and Safety Considerations in the Transport of Radioactive Materials," Unpublished. 
A fire during the transport of the shipping cask by rail or truck is not considered to be a significant hazard. The maximum credible transportation fire is that encountered in an aircraft crash. Calculations have shown* that an aircraft fire would not destroy the cask if it had not already been breached by the accident that caused the fire. In any case, there is no danger of release of the fuel to the atmosphere. Sufficient heat input from the fire would not be available to melt the core since the melting point of the fuel core material is above $2400^{\circ} \mathrm{F}$.

Burial of the loaded shipping cask in an insulating medium through an accident could prove dangerous only if the cask were not located within two days. If the cask were buried in a completely insulating medium, it would take approximately 56 hours for the cask to reach a critical temperature of $2200^{\circ} \mathrm{F}$. The large size of the cask makes it highly unlikely that it could not be located in ample time to prevent the meltdown of the containment material.

Involving the generator with explosives is not within credible limits. Various administrative controls on the shipment will be used to lower the probability of an accident below the levels of Table 2. As is common practice in USAEC carload shipments of enriched uranium and in shipments of weapons components, the placement of the car within the train and even the makeup of the train's cargo may be specified. Requiring that the shipment be placed in the middle of a train and that adjacent cars must not contain certain material, i.e., explosives, inflammable materials, etc., will go far toward minimizing the hazards of shipping a radioactive source of this magnitude cross-country. Railroad personnel consulted on this problem have given assurance that the gondola car will contain the cask under any circumstances short of a complete overturning of the car.

\section{Loading Procedures}

A 10-ton crane will hoist the cask, skid and cage assembly from the trailer and place it in the gondola car at the plant siding. All personnel who may come in contact with the cask should wear protective clothing, heavy gloves, long sleeves, etc, for protection from the hot surfaces of the cask. The cask skid will be blocked and tied down to ensure stability under the maximum shipping forces previously outlined. Care will be taken to ensure that the tiedowns are connected in accordance with the design specifications. Cables or chains will be used for the vertical load tiedowns and will pass over the skid members no more than six inches from the "I" beam connections.

*MND-P-2184, p 44 


\section{GROUND HANDLING*}

The ground support system for preparing the nuclear APU for flight has been designed to eliminate the requirement for a hot cell at the launch complex. This system provides cooling, monitoring and shielding of the fuel capsule during its transfer from the shipping cask into the generator, during ground handling of the fueled generator, and during installation in the missile.

\section{A. AUXILIARY SUPPORT EQUIPMENT}

Certain auxiliary support equipment must be provided to facilitate field handling, core transfer, mating of the final stage and generators, and servicing of the generator on the booster. In addition, certain modifications will be made to existing equipment for servicing the specialized functions of the APU. There are essentially two auxiliary systems: a handling, transfer and mating system, and an umbilical tower system.

\section{Handling, Transfer and Mating System}

A servicing module will accompany the generators to provide cooling of the core, a mercury shield system, radiation monitoring, and control of temperature and mercury levels. Figure 6 is a schematic of this system which specifically provides for:

(1) Cask cooling of core prior to transfer (water).

(2) Generator cooling of core (water).

(3) Compressed gas for pumping mercury (nitrogen).

(4) A mercury fill and drain system for the collar shield and generators (mercury).

(5) Gamma radiation monitors on the cask, collar shield and generators.

* Detailed procedures for ground handling are described in MND-P-2316. 


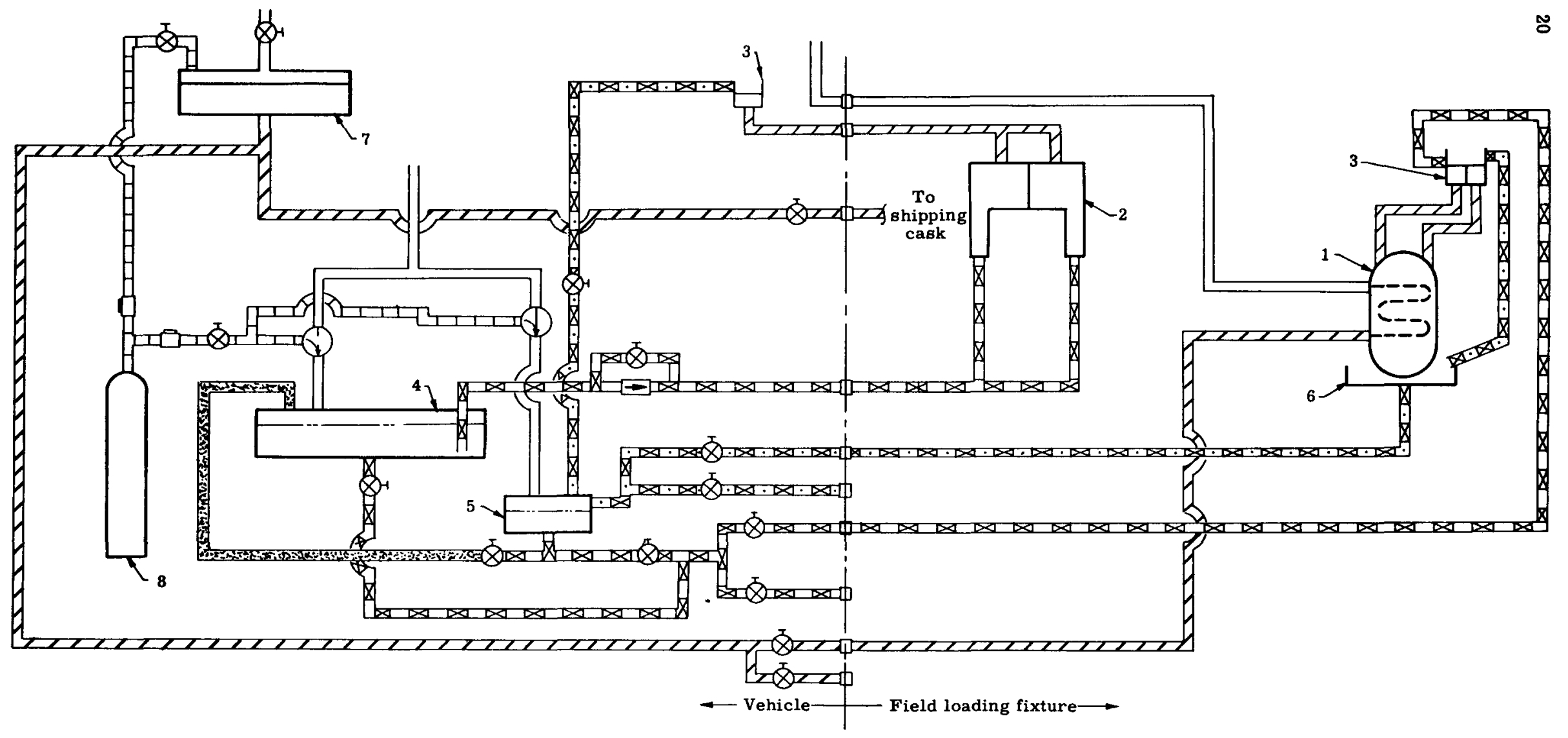

Dercury supply

Mercury overflow return

Mercury expansion

Coolant water supply

$\square$ Vent

Mercury transfer line

वIItrogen
चा上 Disconnect

드 Pressure regulating valve

Z]- Check valve

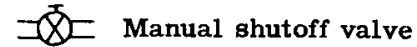

3-way valve (manual)
1 Shield

2 Collar shield

3 Expansion tank

4 Mercury reservoir

5 Sump

6 Splash pan

7 Water reservoir

8 Nitrogen bottle

Fig. 6. Schematic Dlagram--Ground Servicing and Cooling Vehicle Fludd Systems 


\section{Umbilical Tower System}

When the final stage satellite vehicle is prepared for final installation atop the booster, the tower system becomes operative. Figure 7 is a schematic of this system which includes:

(1) Core cooling (water).

(2) Compressed gas for filling and purging the mercury shield (nitrogen).

(3) A shield fill and drain system and reservoir (mercury).

(4) Radiation monitors.

The above services are provided with quick disconnect lines to expedite prelaunch operations. Heavy components are located on the pad with service lines passing through the umbilical tower to the generators.

\section{B. MODIFICATION OR ADDITION TO EXISTING EQUIPMENT}

Modification or additions to the following will be made to facilitate the servicing and handling of the nuclear APU:

(1) Blockhouse control building.

(2) TV cameras.

(3) Umbilical mast.

(4) Remotely operated handling equipment.

These are discussed separately below.

1. Blockhouse Control Building

The blockhouse at the launch pad will house the additional consoles required for testing the APU coolant servicing equipment, consoles for operating remote control equipment for vehicle removal from the booster, and for the shield and cooling line coupling and disconnect. Coolant pressure and temperature recorders, television viewers, and all necessary instrumentation recorders will also be housed in the blockhouse control building. 


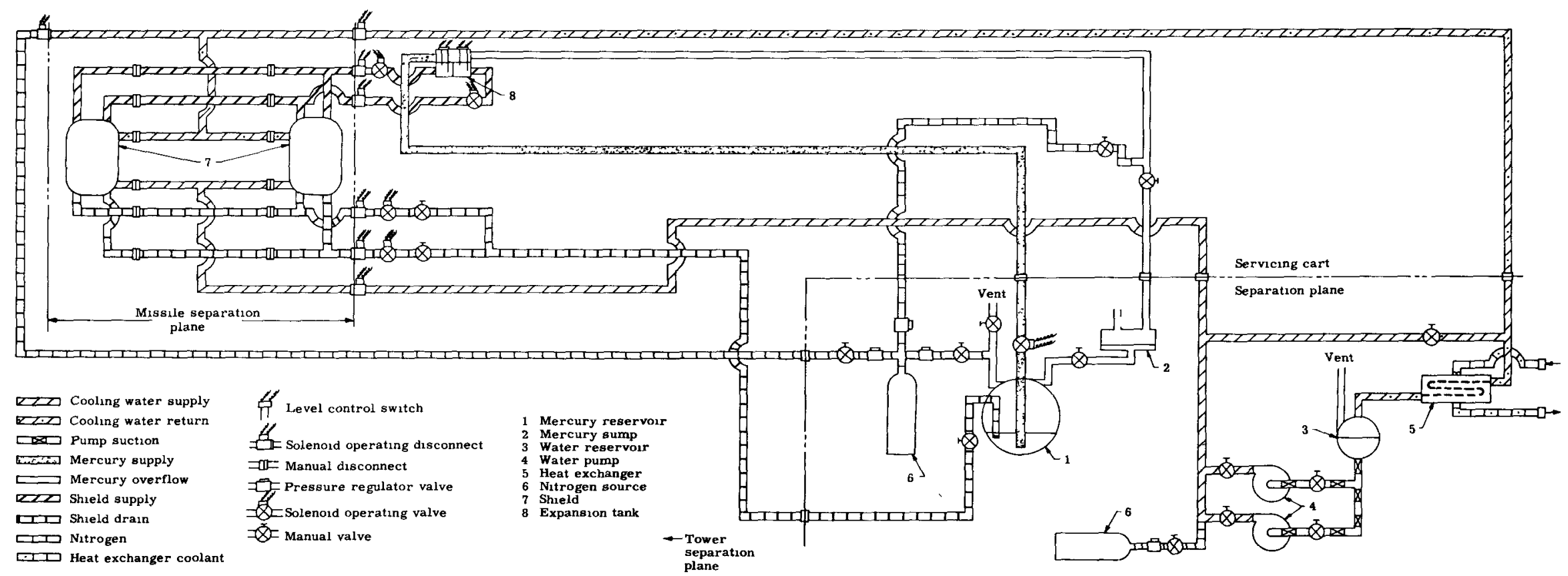




\section{TV Cameras}

TV cameras will be located on the umbilical mast, gantry and pad area so that remotely operated equipment and vehicle components can be observed during prelaunch countdowns. This equipment will also be utilized in the operation and servicing of the APU.

\section{Umbilical Mast}

The structural steel mast used to service the satellite vehicle will be modified and utilized to service the APU. Required modifications to the mast will consist of additional stainless steel piping, valves, and fittings for pumping the APU coolant, mercury shielding and nitrogen gas. A provision will be made for running the necessary wiring to the unit, and for electrically operated valves, sensors and instrumentation. The mast will be fitted with safety devices to prevent the accidental release of the service lines by the vehicles before liftoff.

\section{Remotely Operated Handling Equipment}

In the event that the umbilical connections are released from the satellite prematurely through an equipment malfunction, the mercury shield would be lost, so a method must be available to remotely remove and handle the satellite and APU without presenting a radiation hazard to operating personnel. It has been suggested that, in conjunction with a remotely operated gantry crane, a remotely operated vehicle lifting sling (Fig. 8) be used. The sling would be attached to the gantry crane hook and would be capable of being remotely positioned on the satellite vehicle. Lift arms on the sling would be guided to the vehicle lift holes with the aid of TV cameras located in the gantry. This equipment would be capable of remotely removing a satellite with unshielded APU and placing both in a shielded vehicle for transportation to a disassembly site.

\section{INTEGRA TION OF GENERATORS AND TYPICAL MISSILE}

The Task 2 module, consisting of two generators, is mated to the final stage satellite vehicle at ground level and the complete assembly is hoisted into position atop the booster. Figure 9 shows the overall configuration of the vehicle containing the generators in position atop the booster.

\section{Location of Generators}

As shown in Fig. 10, the generators are located 180 degrees apart and next to the final stage rocket exhaust nozzle in the aft portion of the satellite vehicle. 


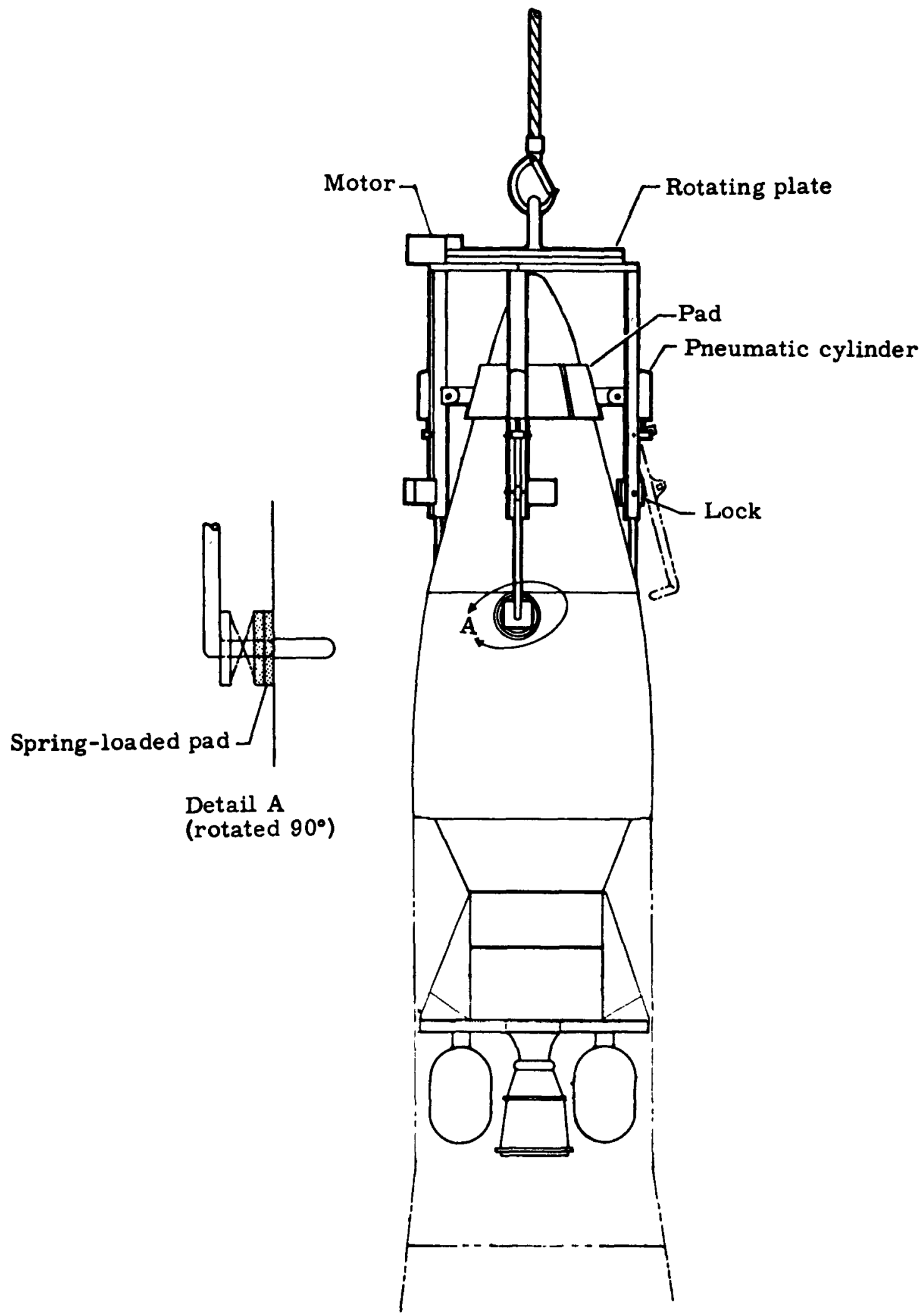

F1g. 8. Remote-Operated SIIng 


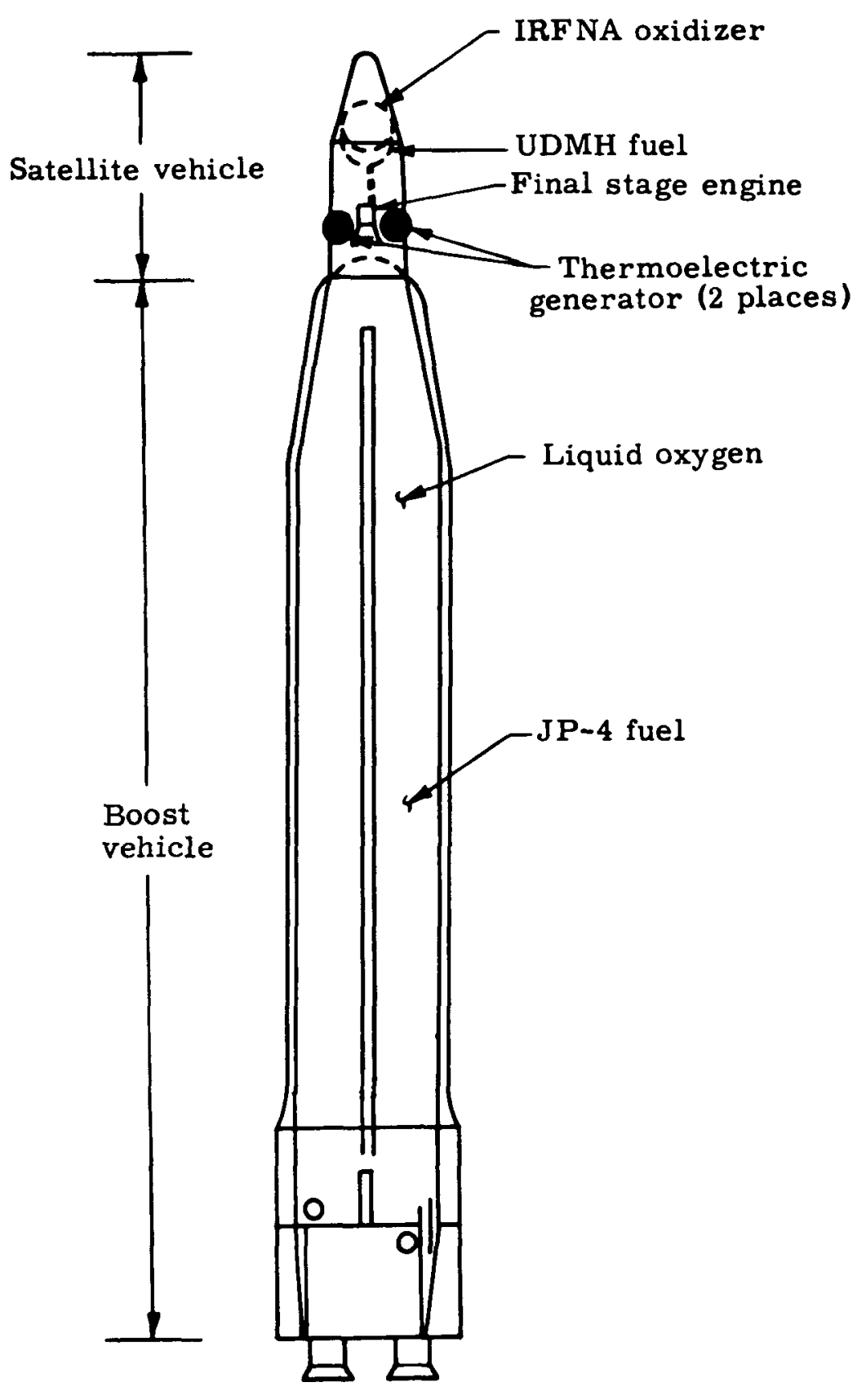

Fig. 9. Typical Vehicle Configuration 


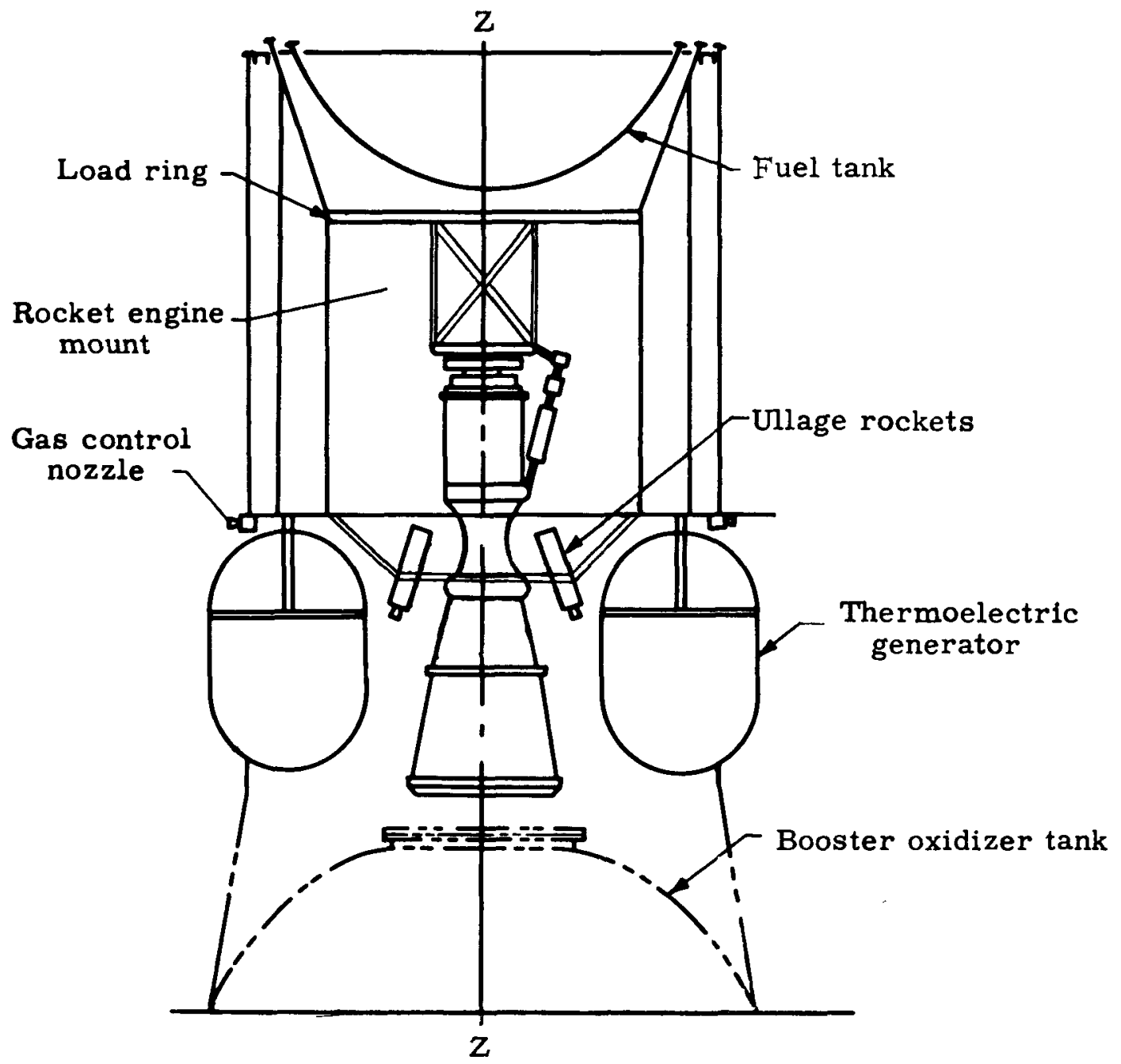

F1g. 10. Aft Section of Typical Satellite Vehicle 
Structural connections. Two generators are attached to the lower frame in the satellite vehicle section of the missile by means of a ring which has been welded to the generators for pickup and attachment to the vehicle frame. Each generator has two columns 180 degrees apart connecting to fittings located on the frame. A minimum number of fasteners are used for rapid and easy installation of the units to the frame. Quick disconnects, remotely operated at the time of launching, are built into the service lines of the mercury biological fill and drain system.

Spatial factors. Several components typical of those necessary for the successful operation of the final stage are located in the aft section of the satellite vehicle with the thermoelectric generators. The generators are positioned so that they do not interfere with either the gimbaled exhaust nozzle of the rocket engine or any ullage rockets or gas control nozzles.

Location relative to fuel tanks. Figure 10 shows the relationship of the generators with respect to the fuel of a typical missile. Both units are located directly above the liquid oxygen tank of the first stage. The final stage propellants, unsymmetrical di-methyl hydrazine (UDMH) and inhibited red fuming nitric acid (IRFNA), are located approximately 40 inches above the generators.

Located under one generator unit is the liquid oxygen boil duct of the booster. The oxidizer of the final stage flows through a duct past the units to the turbine exhaust where it is heated prior to entering the combustion chamber.

Location relative to launch complex. When installed in the missile, the generators are approximately 70 feet above the launching pad. The gantry can be remotely removed to a position 200 feet from the launching pad. When the gantry is removed, the umbilical tower is positioned to service the missile. As shown in Fig. 11, the launch operations building is located about 1000 feet from the launch pad.

\section{PROCEDURES}

\section{Non-nuclear Components}

Upon arrival at the launch site, and prior to mating with the satellite vehicle, the nonradioactive hardware of the APU will be subjected to preflight checkout and inspection testing. Tests and measurements will be made on the electrical control and hydraulic systems and on the biological shield system. A check of the weight and balance of the 


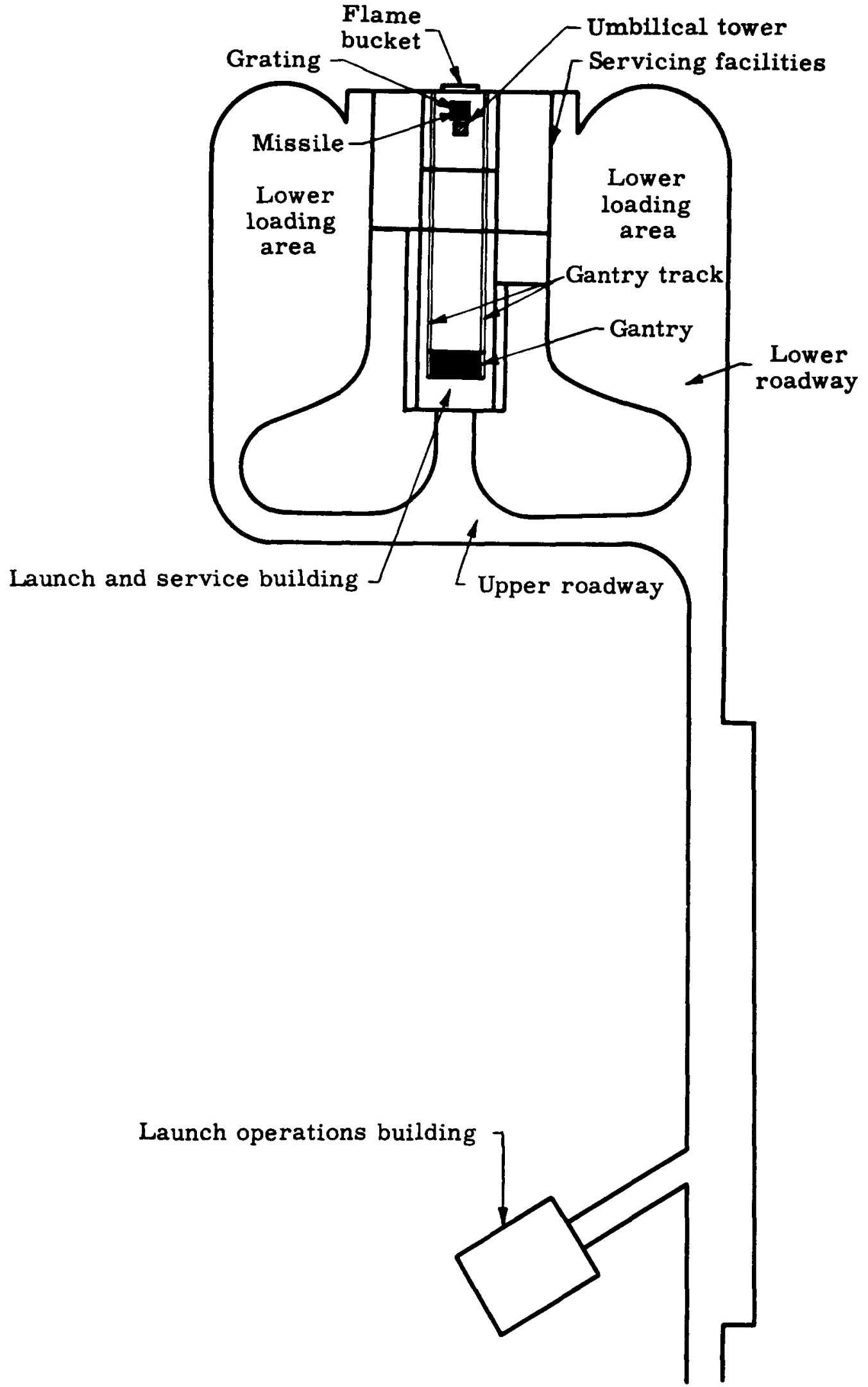

FIg. 11. Sketch of Typical Launch Complex at VAFB 
module with and without mercury would follow to determine dynamic characteristics and effects, and overall operation of the umbilical system would be tested. After mating with the vehicle, final system instrument calibration and checkout tests will be run with an electrical heater simulating the nuclear heat source. The following operations will be performed at this time.

(1) Assembly of the generator to the vehicle to check out the ground support equipment, mating clearances and equipment operation.

(2) Satellite vehicle systems checkout using the electrically heated Task 2 generator:

(3) Umbilical operations with the vehicle.

(4) Checkout of the booster adapter with the vehicle.

(5) Checkout of the remote and nonremote disassembly prosedure.

At the time the satellite vehicle is mated to the booster, the remotely operated crane will be checked out and the TV system will be adjusted. The ground support equipment, including the mercury biological shield system and the cooling system, will also undergo system checkout, both manually at the launch pad and remotely from the control building. At the conclusion of these tests, the Task 2 module is removed from the vehicle and is ready to be loaded with the radioisotope fuel.

\section{Shipping Cask}

Unloading the railroad car. Upon arrival at the launch site, tiedowns between the skid and the gondola will be removed. Before the cask is unloaded from the railcar, the following inspections will be made:

(1) Radiation level at the surface of the cask

(2) Surface contamination.

(3) Wood's metal leakage.

(4) Shipping damage to operating parts of the cask.

Wood's metal leakage is not considered to be serious, and the fuel block transfer process would not be impeded. Damage to the cask such that the operating mechanisms would not function, or a marked increase 
in the radiation level indicating fuel block rupture, would prevent fuel block transfer, and subsequent handling and disposition would have to be determined. Tiedown of the skid to the truck is recommended, but will be the responsibility of the Base Transportation Office. A 10-ton crane will lift the skid, cask and cage assembly from the railcar and place it on a suitable truck or trailer. The long axis of the skid must be oriented with the long axis of the truck or trailer. The speed of the transporting trailer or truck will be limited to $10 \mathrm{mph}$ 。

Transfer of the fuel capsule to generator. A health physicist or radiological safety personnel must be present at all times during transfer of the fuel block. In addition, all persons must wear respiratory equipment specified by the Health Physicist when mercury is being handled.

All persons present in the vicinity during the transfer of a fuel block, and all persons involved in the handling of the loaded shipping cask or power generator, must wear radiation monitoring devices specified by the Health Physics or Radiological Safety Group. To prevent thermal exposure, all persons working with or near the shipping cask should wear asbestos gloves and long sleeved clothing.

A feature in the design of the shipping cask and fuel core transfer equipment is that the transfer of the fuel core to the generator does not require the use of a hot cell and may be accomplished at any convenient location. At the launch complex, the cask will be inverted, hoisted upon a loading stand, and positioned by a portable crane. Simultaneously, a dolly containing the unloaded generator and a collar shield will be positioned in the transfer structure beneath the cask as shown in Fig. 12. The collar shield is a tank of single unit construction and, when filled with mercury, it maintains biological shield continuity between the lead cask and the generator. After positioning, both collar shield and generator are filled with mercury, and the fuel core transfer operation can take place.

The shipping cask shown in Fig. 13 is fitted with two devices to facilitate transfer. First, the bottom of the cask is fitted with a stepped sliding section, which is driven by a screw jack, and which retracts to clear the fuel core for passage into the generator. Second, the core is attached to a stepped hand-operated ramrod which is fitted with a remote connect and disconnect mechanism and is actuated to insert and seat the core in the generator. A cross section of the equipment arrangement is shown in Fig. 14 。

Before the transfer operations are initiated, a checkout of the collar shield and generator mercury system will be made to ascertain proper functioning of level controls, control valves, pumps and overflow sump, and to detect leaks or faulty connections. After satisfactory completion of the checkout test, the equipment is considered ready for fuel core transfer. 


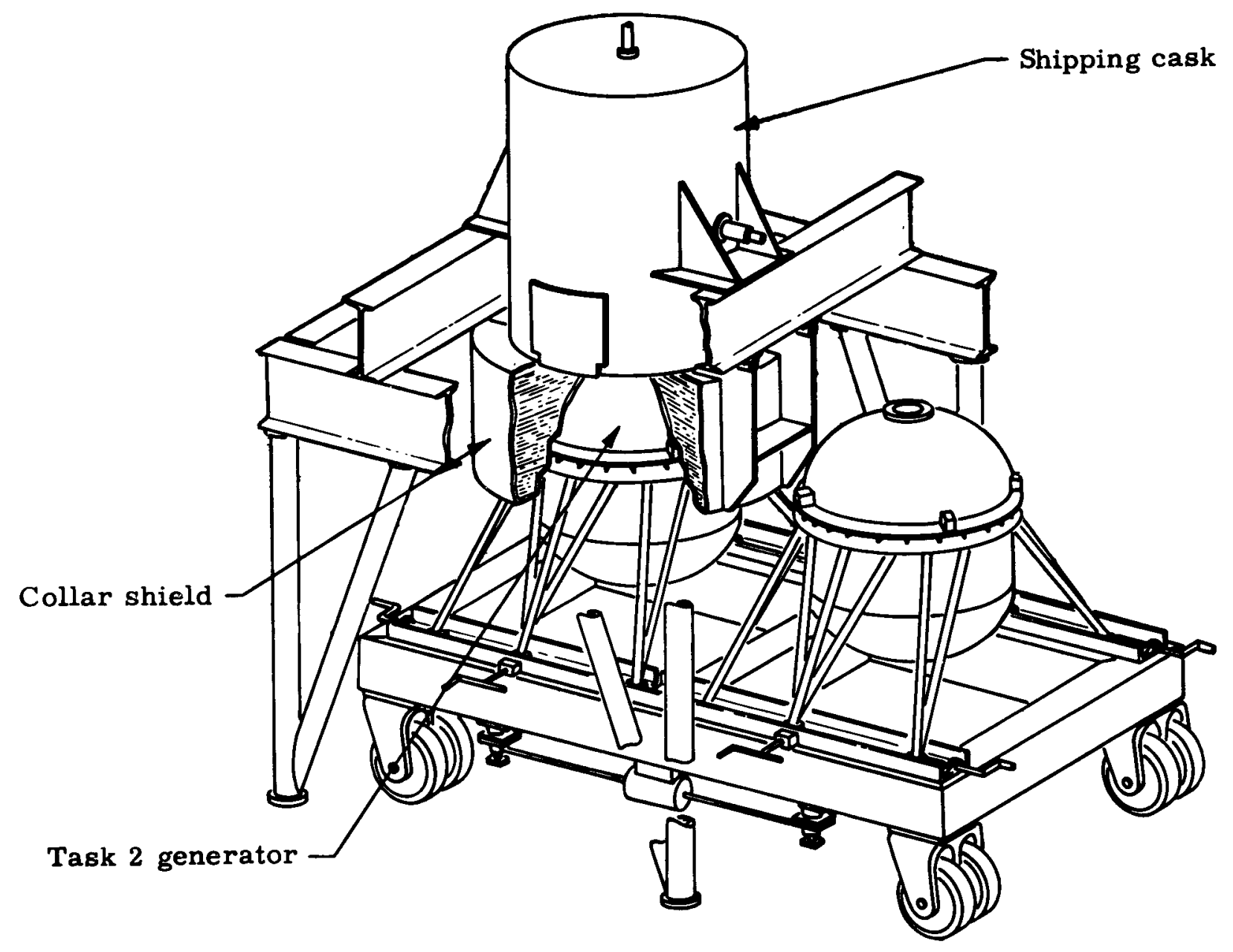

Fig. 12. Transfer of Fuel Core to Generator 


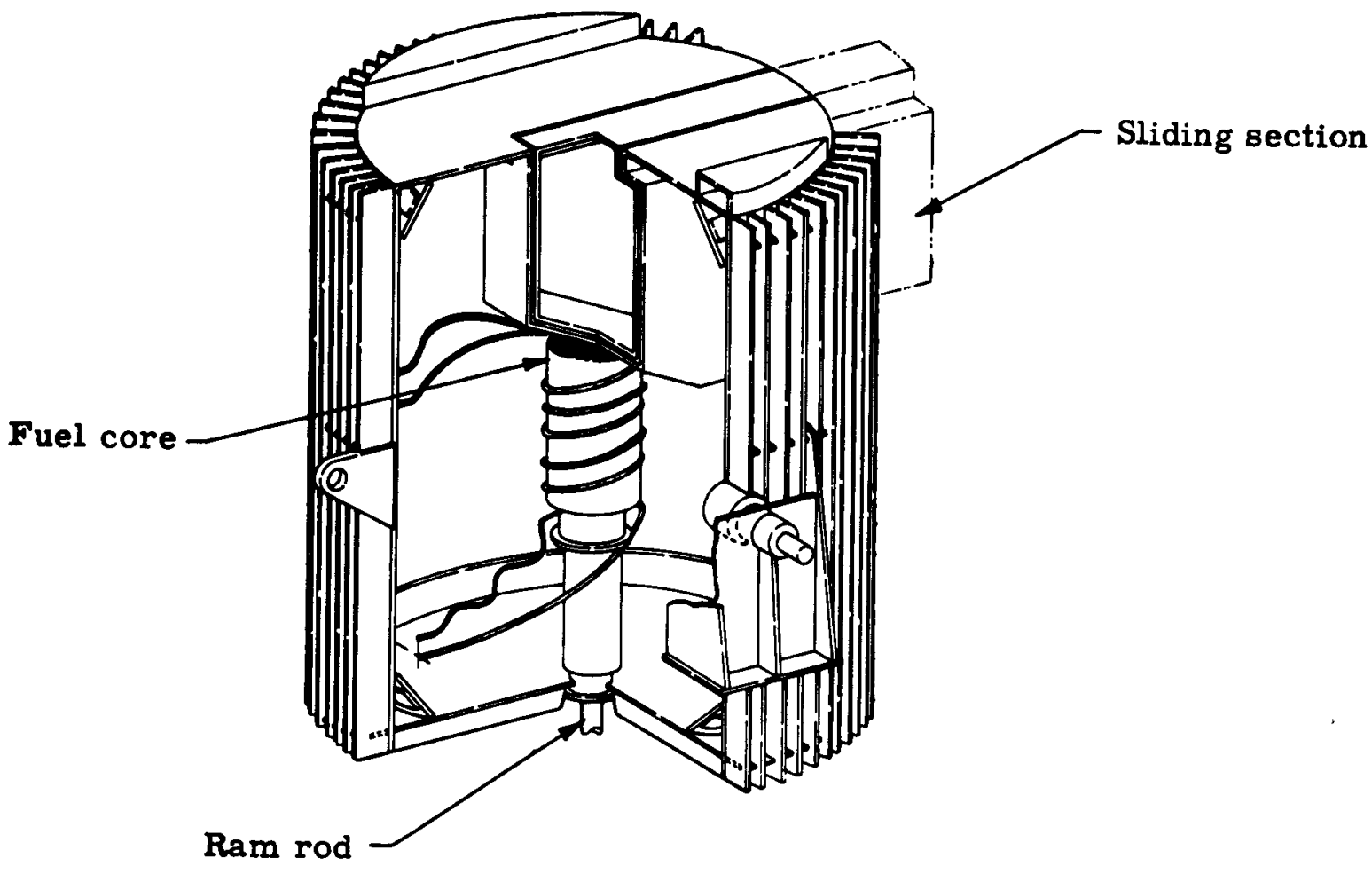

Fig. 13. Shipping Cask (Inverted during fuel transfer) 


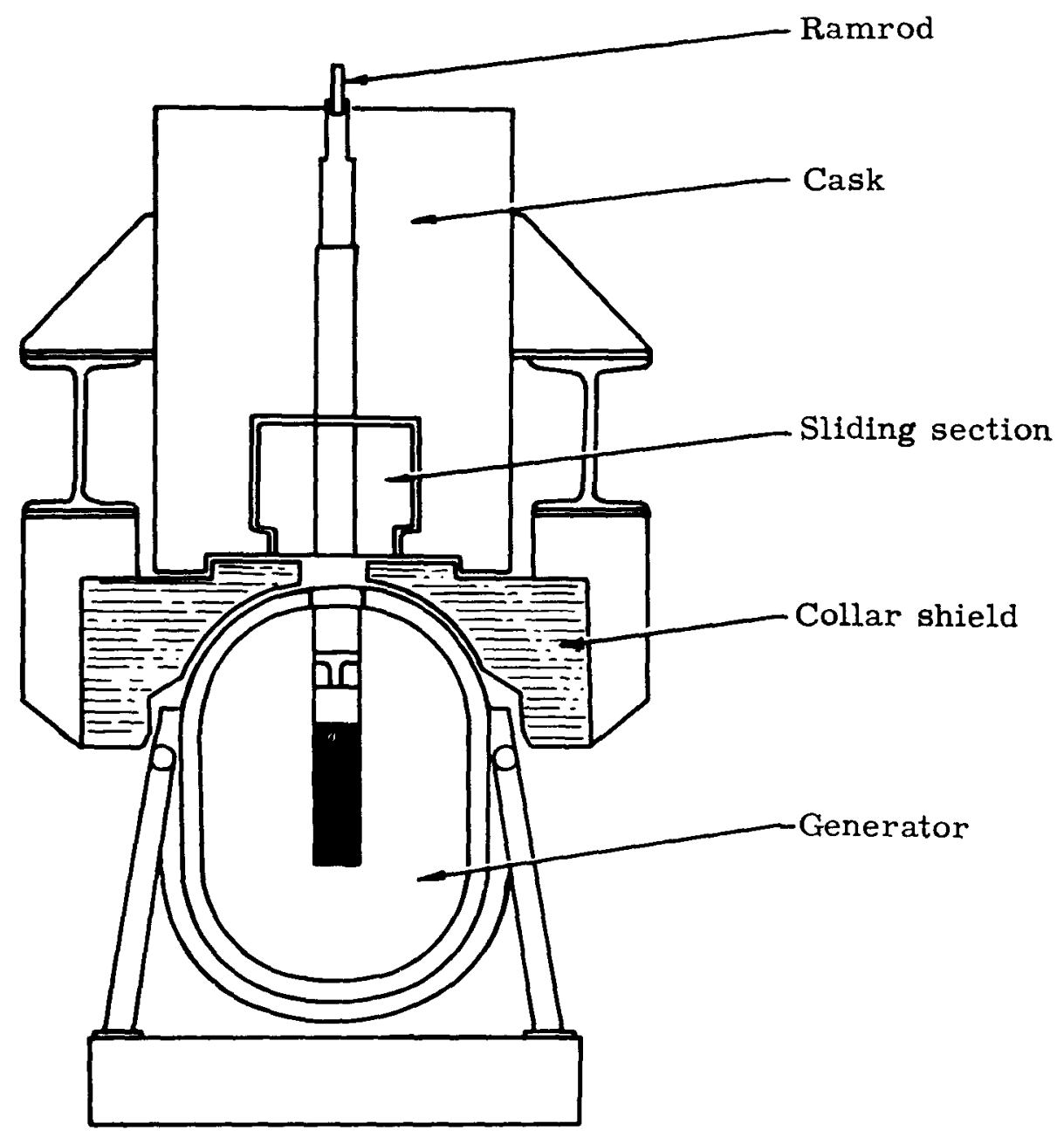

Fig. 14. Internal View of Fuel Transfer Operation 


\section{a. Loading stand operations}

A loading cask stand, designed to support the shipping cask and the collar shield, will be assembled from a readily transportable compact package of "I" beams. After the stand has been assembled and leveled, the cask is removed from the transporting vehicle, inverted, positioned on and bolted to the loading stand. The dolly carrying the generator and collar shield will be rolled under the stand, raised via its built-in jacks and positioned such that the generator, collar shield and cask are in proper alignment. The collar shield will then be bolted to the loading stand. Extreme caution must be exercised in handling the cask due to its weight, high surface temperature $\left(270^{\circ} \mathrm{F}\right)$ and radioactive contents.

b. Fuel core loading procedures

The detailed procedure for the fuel loading of the generators is as follows:

(1) Attach Wood's metal furnace and the heated Wood's metal fill and drain lines to the cask.

(2) Attach coolant lines to cask and to the generator shield and start flow of coolant. The fuel block is ready for transfer to the generator when the temperature at the inner container of the cask reaches $200^{\circ} \mathrm{F}$ minimum and all indicator lights on the control panel flash a safe condition.

(3) Open valves to the collar shield and generator shield and allow them to fill with mercury.

(4) Drain Wood's metal.

(5) Monitor Wood's metal with radiation detection equipment. The Wood's metal may be contaminated. Determine the amount of contamination picked up by the Wood's metal and, if excessive, use portable shielding.

(6) Fit the extension rod to the loading ramrod and remove three lock bolts from the cask where the ramrod extends through the cask.

(7) Actuate the sliding plug.

(8) When the plug is in full open position, lower the core into the generator with the ramrod until the fuel core enters the mercury. At this point, the core will begin to float and force must be exerted to submerge it in the mercury. 
(9) Continue to force the fuel down into the mercury until it is bottomed. Due to core displacement, mercury will begin to spill into the overflow line provided.

(10) When the core is bottomed, rotate the ramrod until the locking device engages the core.

(11) The ramrod is released from the core and withdrawn. The transfer is complete.

(12) Remove mercury from collar shield, unbolt the collar shield and remove the generator from loading stand.

(13) Insert tungsten block into generator.

(14) Seat and secure the generator loading hatch.

c. Mating of generators to final stage

After the dolly-mounted generators are fueled, the dolly is moved underneath the final stage mating structure as shown in Fig. 15. Since the generator is designed for tension loads, it must be loaded into the final stage vehicle in a vertical position. Once the generators are positioned on either side of the engine nozzle, they are jacked upward and secured to the missile support ring with explosive bolts. Throughout this operation the mercury shield is maintained within the generator.

\section{d. Mating of satellite vehicle to booster}

After the auxiliary power unit has been mated to the satellite vehicle, the vehicle is hoisted into position atop the booster. As long as the hoisting operation is completed within two hours, the generator cooling system need not be in operation since the mercury shield represents a heat sink of considerable magnitude. Mercury cooling and circulating lines must be attached after the vehicle has been positioned. Two Task 2 generators will add approximately 8400 pounds to the weight of the satellite vehicle. Of this, 8000 pounds is due to the mercury shield of the generators.

\section{e. Countdown}

The generator auxiliary systems will function from the umbilical tower from the time the gantry is removed up to launch. At $T=-300$ seconds, the mercury is drained from the shield. At $\mathrm{T}=-50$ seconds, the mercury will be completely purged from the shield and the temperature at the generator hot junction will begin to rise, reaching design operating conditions in orbit at $T=+3300$ seconds. Service lines do not disconnect until the vehicle lifts off the pad. If any hold occurs in the prelaunch countdown, the mercury may be returned to the shield to facilitate work in and around the vehicle. 


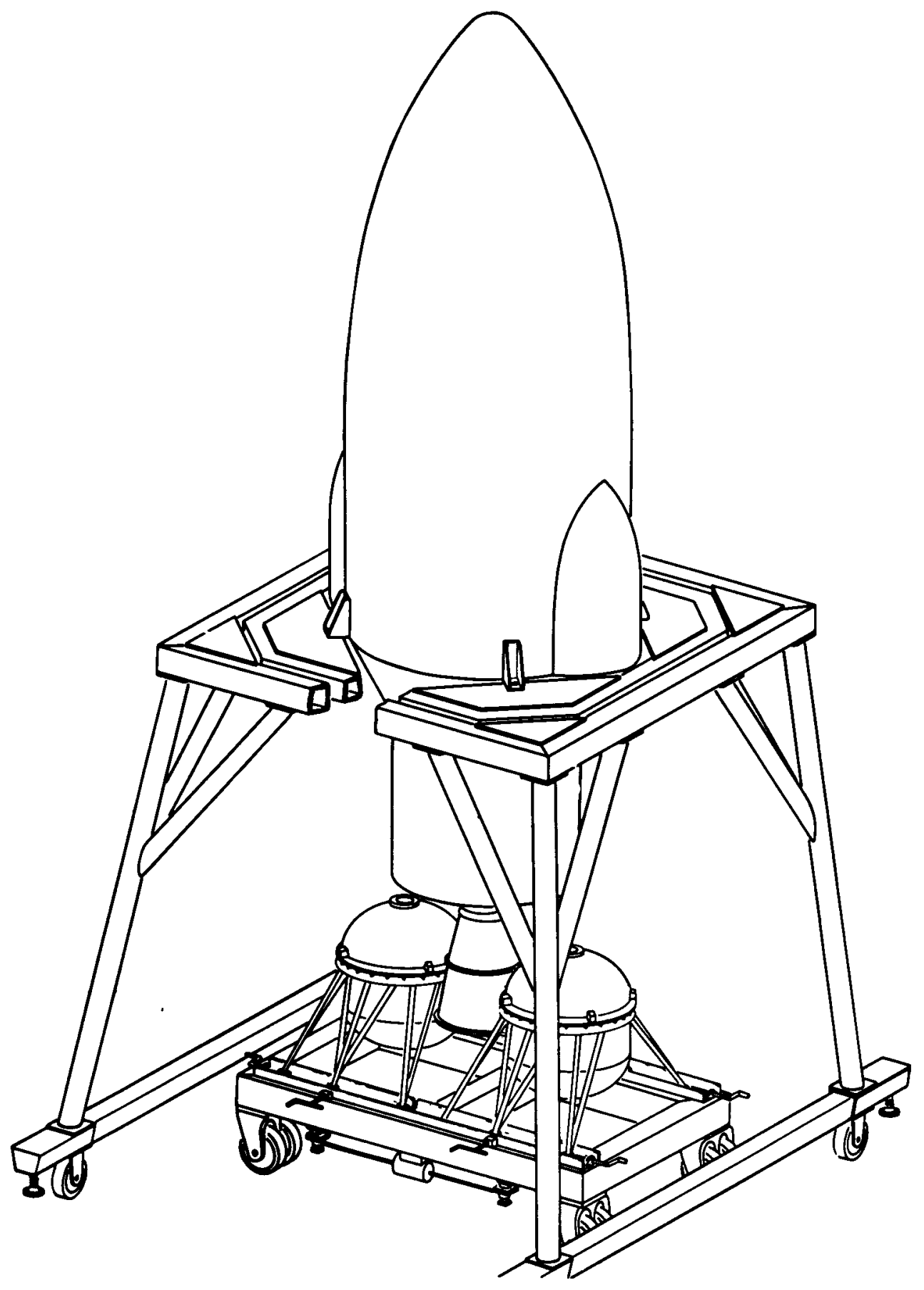

FIg. 15. Mating of APU to Satellite Vehicle 


\section{ABORTED FLIGHT PROCEDURES}

\section{A. ABORT CLASSIFICATION}

The launch aborts of interest may be classified as shown in Table 3.

\section{TABLE 3}

Abort Types

(1) Prelaunch abort

(a) Prelaunch countdown stopped after mercury shield drained.

(b) Violent prelaunch abort.

(2) Launch abort

(a) Abort in launch pad area.

(b) Wreckage on or near blockhouse.

(c) Abort resulting in impact on land somewhere between launch pad and Pacific Ocean.

(d) Abort over Pacific Ocean.

\section{Prelaunch Abort}

(a) Prelaunch countdown stopped after mercury shield drained

Umbilical mast connections for servicing the APU are designed to maintain contact with the satellite vehicle until the missile has lifted from the launch pad. For a stop during prelaunch countdown, all that is required is to pump the mercury back into the APU shield. In the event that a malfunction of the umbilical tower has broken the service connections, remote handling techniques will be utilized to place the APU in a safe state.

A redundant, remotely operated generator shield system will be built into the gantry tower to provide a backup system in the event that an umbilical mast malfunction allows the APU service lines to disconnect from the missile prior to liftoff. For any particular configuration of 
booster and satellite, the gantry and vehicle will have a constant orientation; therefore, the design of a remotely operated mechanism to place the service lines of this secondary system in contact with the APU service lines on the vehicle will present no great difficulty. Radiation monitors on the gantry will provide information on the success or failure of this attempt.

Previous systems ${ }^{3}$ suggested to place the APU in a safe configuration have called for the removal of the satellite from the booster by blowing the explosive disconnects and then remotely placing the vehicle on the mating fixture and reconnecting the service lines. If the service lines are not remotely replaceable, the generators would be removed from the vehicle by blowing explosive disconnects and then buried. In order to prevent unnecessary damage to the booster and vehicle caused by the blowing of the explosive disconnects, this system would be used only as a backup to the remotely operated system in the gantry tower.

If the APU servicing system in the gantry malfunctions due to an inherent defect in the service lines or quick connects within the vehicle, the previously outlined system of vehicle removal and separation from the Auxiliary Power Units will have to be followed. The probability for such an occrrence is small, however, due to the simple connection mechanisms involved in the servioing system.

\section{(b) Violent prelaunch abort}

While this case has occurred due to an explosion during the prelaunch fueling of the missile, the characteristics of the resulting retrieval problem are identical to those in case (2) (a) of Table 3, abort in launch pad area.

\section{Launch Abort}

Cases (a), (b), (c)

Failures in the missile system occurring from $T=0$ to pitchover at $T=+15$ seconds will cause the missile to impact within the launch pad area (case $(2)(a))$. Failures after maximum dynamic pressure on the ascent trajectory $T=+60$ seconds will in all likelihood impact in the ocean downrange from the launch site. All cases of impact on land or shallow sea areas near the launch site will be caused by a missile failure prior to $T=$ approximately +90 seconds. No significant differences in the characteristics of the wreckage expected in cases $(2)(a),(2)(b)$ or $(2)(c)$ of Table 3 can be predicted since, in all cases, major damage is done by fire and explosion.

3ockheed Aircraft Corporation, "SNAP Facility and Accessory Equipment," LMSD-445405, July 15, 1959, SECRET. 
The problem in all cases, therefore, is one in which the APU must be located and separated for handling from among scattered missile wreckage. There are three possible generator missile wreckage configurations in an abort. These configurations may be classified by the complexity of the remote handling operations required for fuel cores retrieved as follows:

(1) Fuel cores easily accessible, i.e., fuel cores free of all entangling missile and generator wreckage.

(2) Fuel cores accessible with minimum difficulty through an easily predicted sequence of recovery operations, i.e., relatively undamaged generator thrown clear.

(3) Fuel cores are retrievable only by a complicated unpredictable sequence of operations, i.e., the fuel cores are contained in damaged generators which are attached to the vehicle or are entangled in the vehicle wreckage.

Information on the probability of various wreckage configurations obtained from a study of pictorial records and accident reports at Cape Canaveral is available. ${ }^{4}$ From this information, some conclusions may be drawn as to probable fuel core missile wreckage configurations. Configurations (1) and (2) above do not appear to be very likely. An ejection mechanism for the 196-pound, Task 2 generator, to ensure a type (2) wreckage configuration, appears to impose a sizable weight penalty on the satellite system. Configuration (3) appears to be the most likely one. As a general case, sizable missile fragments do not bury themselves in the soil of the launch site, and isolated parts are deposited much less frequently than entire or partial assemblies that are heavily damaged and in disarray. The evidence at Cape Canaveral strongly indicates that the APU will be located among a mass of scattered wreckage and must be separated from an assembly such as configuration (3) above.

Case (2)(b), wreckage on or near blockhouse, presents additional problems due to the high radiation field of the two generators, and the possibility that salvage equipment will not be able to approach the units on the roof of the blockhouse because of their great weight. The dose rate within the blockhouse due to two unshielded generators on the roof would be low, approximately $1 \mathrm{mr} / \mathrm{hr}, 3$ feet above the floor. This is due to the heavy concrete construction of the blockhouse and the overlaying soil. Removal of personnel from the blockhouse becomes a critical operation if the power units remain on the blockhouse roof or in the vicinity, since the gamma dose rate 100 feet from two unshielded 125-watt APU's is $46 \mathrm{r} / \mathrm{hr}$.

${ }^{4}$ AFSWC, "Recovery of The Nuclear Auxiliary Power Source of a Missile After a Launch Abort," AFSWC-TR-59-46-DK-1255-P-2, October 1959. 
(d) Abort over Pacific Ocean

Post-launch aborts after $\mathrm{T}=+60$ seconds will impact in the Pacific Ocean downrange from the launch site. The bottom of the ocean adjacent to the missile range slopes rather uniformly to a depth of 240 feet at about 4 miles off shore. If recovery is to be attempted, it must be in this area. Launch aborts after $\mathrm{T}=+90$ seconds will impact too far down range for retrieval. The characteristics of the wreckage from a sea abort are similar to those to be expected from other post-launch aborts. Major damage will be done by fire and explosion but no postimpact fire will be present to help locate the missile wreckage.

\section{B. SEARCH AND RECOVERY}

A launch into a polar orbit at the Pacific Missile Range sends the vehicle in a southerly direction over approximately 8 miles of Government and private land and out over the Pacific Ocean. All post-launch aborts prior to $T=+60$ seconds will most likely impact on land between the launch pad and the Pacific Ocean. An exclusion area into which the missile might fall on a launch abort can readily be established. The fallback zone, from which personnel are excluded both before and immediately after a launch, is approximately 25 square miles in area. In this zone, the terrain is hilly, the ground is, in general, of a sandy or shale composition and vegetation is sparse. The launch operations building is the only part of the fallback area in which personnel are present (see Fig. 11).

In present practice, a missile accident emergency team (MAET) stands by during every firing at a spot just outside the fallback area. The team, which consists of a safety technician in charge, a medical group, a photographer, missile engineer, and an explosive ordnance demolition expert, is in constant communication with the blockhouse and is equipped with a fire truck. An M-246 wrecker, a 20-ton crane, a D-8 tractor on a flatbed trailer and an $\mathrm{H}-19$ helicopter are in standby at the motor pool. With the addition of Health Physics Personnel and additional remote controlled equipment and operators, this team could be utilized in recovering the APU from an aborted launch.

\section{Equipment}

At present, a number of shielded vehicles primarily intended for the servicing of ANP aircraft are in the design and construction stage. These vehicles could be modified for use in retrieving an APU following an aborted flight. However, they cannot be used in recovering APU's which have impacted upon the blockhouse roof, since the great weight of these vehicles would damage the blockhouse structure. This prob- 
lem can be solved by using light remotely operated equipment to pick up the APU and associated wreckage and move it to an area accessible to the heavy shielded vehicle. The operators in the vehicle would then use the remote handling equipment to separate the APU from the wreckage and place the cores in a safe configuration.

Use of shielded vehicles as opposed to unshielded remote controlled vehicles in the recovery of a nuclear APU is based on the early availability of this type of vehicle. A shielded vehicle can theoretically place a man at the site of the wreckage of a nuclear APU, where he can make decisions on recovery procedures based on personal observations. In practice, the large amounts of shielding required to permit close approach to a radioactive fuel core by a manned vehicle obstructs the view and may require the use of indirect viewing devices. It has been shown that driving an army truck over rough terrain by use of $\mathrm{TV}$ viewing is easier than driving a tank by use of a periscope. A light remotely controlled vehicle, while requiring a command car, is not limited to where it may travel by its weight and has the added advantage of not being outdated by an increase in source strength. It is believed that, for a long range program, light remotely controlled recovery equipment is desirable.

\section{Operations}

Operations performed in attempting to retrieve an APU after an abort may be classified as search, handling and disposition.

Search. The time scale of the recovery operation depends on the location of the radioactive fuel cores. Impact on or near the blockhouse, the most urgent case, does not constitute a difficult search problem since the blockhouse area is under visual observation during the launch. Since no personnel are present elsewhere in the fallback area, ample search time exists if the wreckage falls more than 1000 feet from the blockhouse. The existence of privately owned property and a railroad right-of-way in the fallback area make it mandatory that the radioactive material be promptly recovered. Locating the fuel cores by ground vehicles in the hilly 25 -square mile fallback area would be a dangerous, time-consuming process because of the hazard that the bare source presents to an unshielded manned vehicle upon a sudden close range encounter. Airborne search is more desirable from a speed and safety standpoint. As shown in Fig. 16, a very nominal dose would be obtained by a search plane crew passing in proximity to the sources.

Airborne radiometric surveying techniques, which were developed by the AEC primarily for aerial prospecting for uranium, appear to be applicable to the search for a point source. Present day scintillation 


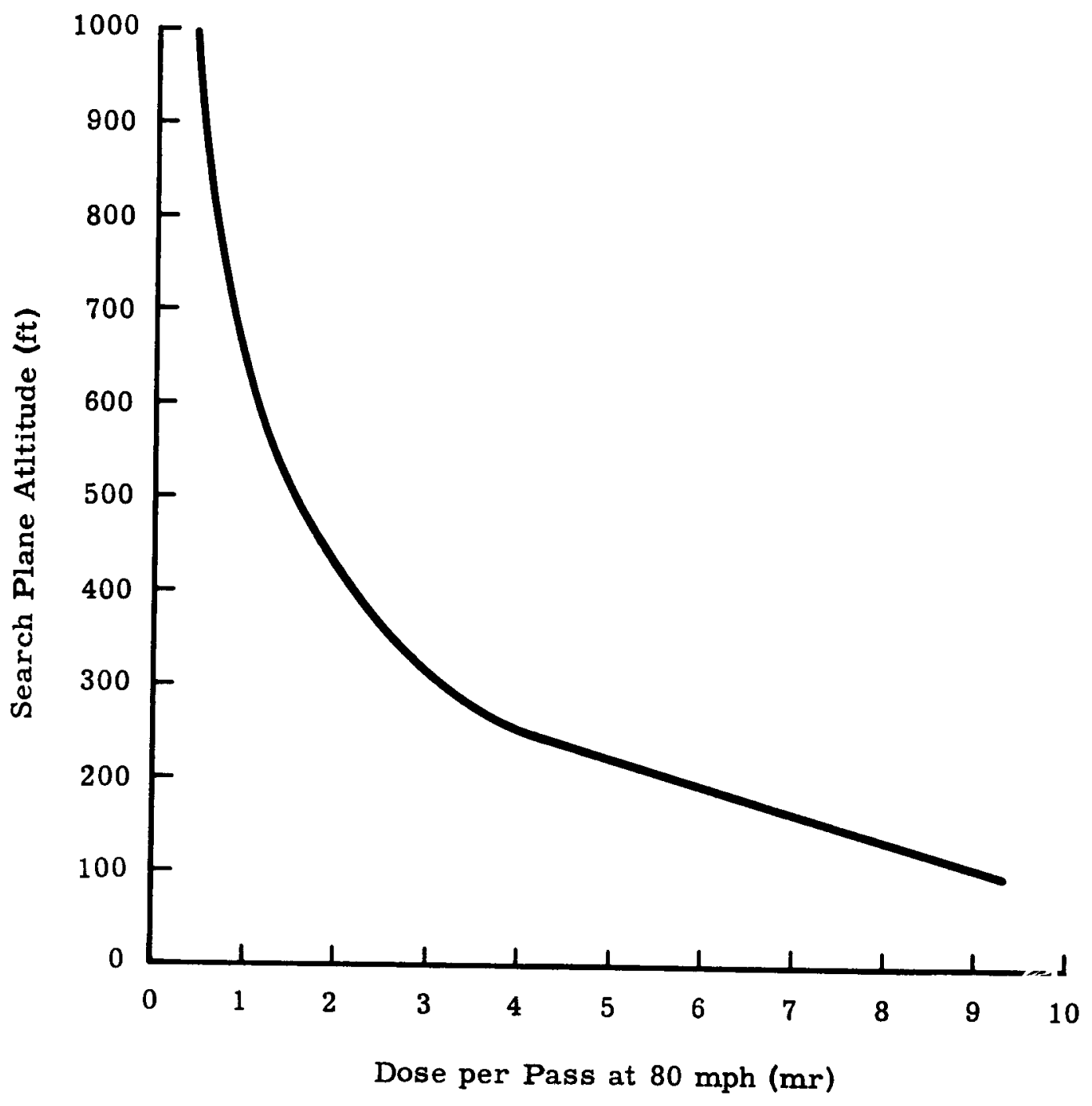

F1g. 16. Garma Dose to Search Plane from Two SNAP IA Generators 
counters located below the search aircraft can give a rather broad peak on a galvanometer record, and exact source location could be established by several passes in a criss-cross pattern. A search time of 6 hours for a 6-square mile area is feasible with this equipment. For accurate pinpointing of the target location and determination of the access route, the aerial search should be followed by target location from the ground by a vehicle in contact with the search plane. The unshielded command vehicle will assume this function while it is guiding the handling vehicle to the target.

Handling. Due to the inherent unpredictability of the manner in which a missile aborts, the final fuel block missile wreckage configuration cannot be predictea. Therefore, the salvage and handling tasks will only be described in a general manner. In this respect, the problem will be discussed utilizing remotely controlled equipment because of its long range desirability, although shielded equipment presently under development can be substituted in most areas.

Within the launch pad area, there is no problem of access to the wreckage. The remote handler would approach the wreckage and deter mine which particular "assembly" held the generators, either visually through the TV eyes of the vehicle or with built-in radiation detection equipment. If the generators have to be separated from the wreckage, a small explosive charge could be used as a preliminary sorting operation, followed by cutting tools to remove the gross attachments to the generators. Abrasive cutoff wheels, torches and hydraulic shears are some of the equipment which might be utilized in this task. Once the generators are relatively free of the missile wreckage, they would be transported to the storage site.

If the missile wreckage impacts upon other areas of the launch site, the problems involved differ only in the early stages, and are those of maintaining contact with the remotely controlled vehicle and clearing the area enough to allow operation of the equipment. An initial bulldozing operation may be necessary to remove massive wreckage from terrain in which it is not possible to perform the required separation operations, and to clear the wreckage site for subsequent operations on the nuclear source. In order to maintain contact with the remote handling vehicle, a line-of-sight radio and TV transmission is required. Should the terrain features and the radioactivity of the source combine to prevent this, the command car will carry a TV antenna on a telescoping mast, and a portable repeater station to ensure continuous contact with the handling vehicle.

Disposition. Immediate burial of the remains of the generators in a prepared pit would appear to be the most straightforward disposition. However attractive this idea may appear, this can only be a temporary expedient. Due to the high cost of the fuel, salvage of the cores will be an eventual requirement. 
The APU fuel cores will be shipped to Vandenberg AFB in shielded casks. These casks will most likely be used for the return shipment of the cores in the event of an accident. In test programs conducted by The Martin Company, the Task 2 fuel core has been impacted against material similar to that found at the launch site (earth and unconsolidated rock) without deformation. Based on the test program, no deformation of the fuel core due to impact at the launch site can be expected, and the use of the shipping cask for the return shipment of the fuel cores appears feasible.

The accidental or automatic freeing of the fuel core during an abort is not expected. In fact, the damage to the generator is likely to complicate the problem of fuel core removal, dictating the use of cutting tools for disassembly. Therefore, provisions for temporary safe storage must provide access to the unit to permit mechanical separation of the fuel core from the generator.

In view of the possibility of encountering problems in removing the capsule from the generator, and because cutting operations may be performed under water in full view of the operator, a water pool providing sufficient operating clearances and adequate shielding appears to be the best temporary disposal means.

\section{Summary of Search and Recovery Operation}

A typical search recovery sequence will be described to illustrate the procedures to be used in an operation of this type.

It is assumed that visual tracking information has designated a 6 square mile impact area, downrange from the launch pad. Search helicopter and command car are both provided with identical maps of the area. The search aircraft starts first from the Vandenberg airfield, and locates the approximate position of both generators, either visually or with the airborne search equipment. While more precise air location is underway, command and handler vehicles start off together from the MAET observation post at the edge of the fallback area.

The search aircraft circles the site from a safe distance, and by radio contact assists the command vehicle to obtain visual access to the site at a minimum of 1000 feet, where the radiation intensity is $0.08 \mathrm{r} / \mathrm{hr}$. If the terrain does not permit this approach, the repeater station is interposed between wreckage and command car. When the command car has visual access to the site, the remote handler proceeds there under the control of the command car under visual observation and guidance from the search aircraft. 
When the handler has reached the site, the wreck is examined via $\mathrm{TV}$ from the command car, and a decision on the operations required to separate the generator fuel core from the missile wreckage is made. The aircraft can withdraw at that time.

After separating the generator, the handler, under control from the command car, proceeds to the water pool. During the transport operation the command car keeps a safe distance from the radioactive source with the aid of its monitoring instruments. Burial of the fuel core offers the simplest method of storage for the earliest flights of a nuclear APU.

Transfer of the generator into the water pool is the final operation. Subsequent fuel core recovery operations can be carried out at any desired future time, using remote handling equipment, lead shipping casks, etc.

\section{Underwater Salvage}

The bottom of the ocean adjacent to the missile range slopes rather uniformly to a depth of 240 feet at about 4 miles off shore. Thus, impact of the aborted missile in this area would allow salvage operations to be carried out. Since the fuel core is highly resistant to corrosion, dispersal of the radioisotope is not a hazard. Salvage operations would have to be dictated by the value of the contained radioisotope to the AEC. At present, there does not appear to be real desire to expend the necessary funds to recover the fuel cores from a sea abort.

The following procedures are suggested as a starting point for further work to be done in investigating marine salvage operations which would be suitable in the event it is desired to recover an APU from a sea abort.

As is the case with land aborts, the problems are those of remote search, handling, or disposition.

Search. The impact area will be located by shore observers through either visual or radio triangulation of the falling missile. More precise location of individual sections of the missile will be made by ships sent to the scene immediately after the abort. Identification of the APU will be made either visually or with an underwater probe similar to that used in the underground logging of uranium deposits. The possibility exists that the search ships may approach to within dangerous proximity of the radioactive fuel core. For this reason radiation detection instruments would be in continuous operation on the search vessel and would be either continously monitored or equipped with an audible alarm to sound a warning upon entering a dangerous radiation field. Skin divers 
can approach to within 9 feet of the two generators under water without experiencing a dangerous dose. Dive feet of water reduce the radiation intensity from two Task 2 generators to approximately $10 \mathrm{mr} / \mathrm{hr}$. If the divers were to work a full eight-hour day at this distance their total dose $(72 \mathrm{mr})$ would be less than the permissible dose for long term exposure to $\mathrm{X}$-rays ${ }^{5}$ (100 $\mathrm{mr} /$ day). All personnel engaged in the recovery of the APU should wear appropriate radiation monitoring equipment to record the integrated total dose received during the recovery operation.

Handling. After the missile wreckage has been located, the search vessels will criss-cross the area with the underwater probe to locate the wreckage containing the two generators. Skin divers will enter the water carrying radiation detection equipment to approach the generator and visually ascertain the handling procedures to be used in recovering the fuel cores. Detection equipment will be used to warn of close approach to the generators. In all likelihood, the generators will be tangled in some large piece of missile wreckage. Some work will be required to make the generator amenable to separation of the fuel core and placement in a safe configuration for storage or shipment.

It is not desired to undertake complicated remote separation procedures on the ocean floor, therefore, if any large sections of wreckage are attached to the generator only the crudest sort of operations will be attempted. Explosive charges positioned remotely may be used as a preliminary separation aid for the removal of the larger pieces of wreckage from around the generator. Since the fuel core is designed to retain the radiocerium in the event of a booster rocket explosion, there is no danger of rupture of the fuel core due to the shock of the small charges used in this operation.

Actual removal of the APU from the ocean floor would be accomplished with a seagoing crane. Skin divers in the area would guide the clam shell bucket to the wreckage containing the APU. Long leads from the bucket would be used by the divers for positioning the bukcket while remaining outside the dangerously radioactive area adjacent to the fuel cores. The crane used for this operation could be quite small due to the low weight of the unshielded generator (200 pounds). An alternate pickup method involves the use of a strong net guided to the desired assembly on the ocean floor by the skin divers.

Disposition. Facilities provided for the disposition of a land-impacted fuel core would be utilized in disposing of the fuel core after it had been returned from the sea. A temporary lead wall at least 13 inches thick built on the retrieving ship or an auxiliary barge could be used to shield the generator wreckage. Care must be taken that personnel are not

5

National Bureau of Standards, "Permissible Dose from External

Sources of Ionizing Radiation," Handbook 59, September, 1954. 
exposed to the radiation from the fuel core during the period in which the generator is being transferred from the water to the lead shield. At the dock, the remote handling vehicle would transport the generator to the storage site.

The high temperature of the generator fuel core poses another hazard, If the fuel core is submerged in the sea, it will reach a temperature of approximately $178^{\circ} \mathbf{F}$. In air, however, the surface temperature will approach $1450^{\circ} \mathrm{F}$ at equilibrium. The hot fuel core could have deleterious effects on transporting vehicles and handling equipment. For this reason, it is desirable for the fuel core to remain in water during the retrieval operation even up to the point where the remote handling vehicle picks up the fuel core for transporation to the storage site.

Possible methods for transporting the fuel core from the recovery area to the remote handling vehicle pickup point include: (1) towing the fuel core underwater in the pickup apparatus and, (2) using a water-filled well such as is available on commercial fishing vessels. In the latter case, a floating drydock type of vessel could be sunk to receive the APU, the hull compartment could be pumped out leaving a central pool in which the APU could be transported. As indicated previously, only nine feet of water would be required to attenuate the radiation from the fuel cores to a safe level. 
page blank

\section{that}




\section{BIBLIOGRAPHY}

Dix, G. P. "Preliminary Operational Hazards Summary Report for the Task -2 Thermoelectric Generator," The Martin Company, MNDP-2184, December 1959. SECRET-RESTRICTED DATA

Lockheed Aircraft Corporation, "SNAP Facility and Accessory Equipment," LMSD-445405, July 15, 1959. SECRET

AFSWC "Recovery of the Nuclear Auxiliary Power Source of a Missile After a Launch Abort," AFSWC-TR-59-46.

Lockheed Aircraft Corporation, "SNAP-1 Evaluation and Development," LMSD-6044, April 23, 1959.

Reilly, M.J. "Preliminary Technical Manual Loading, Shipping and Test Procedures for the Task-2 Isotopic-Powered Thermoelectric Generator," MNP-P-2316, February 24, 1960.

National Bureau of Standards, "Maximum Permissible Body Burdens and Maximum Permissible Concentrations of Radionuclides in Air and Water for Occupational Exposure," Handbook 69, June 1959.

National Bureau of Standards, "Permissible Dose from External Sources of Ionizing Radiation." Handbook 59, September 1954。

Spamer, A.M., "Shielding of Cerium Sources," (Unpublished Reports), The Martin Company, 1957, 1958, 1959 and 1960 .

Strominger, $D_{0}$, Hollander, $J_{0} M_{0}$, and Seaborg, $T_{0}$, "Table of Isotopes," Reviews of Modern Physics, Vol. 30, No. 2, Part 2, April 1958.

Task 2 Quarterly Progress Reports

Knapp, Harold A., et al. "Cost and Safety Considerations in the Transport of Radioactive Materials," Unpublished.

Batie, Ralph $\mathrm{V}_{\text {os }}$ "Shipping of Radioactive Materials at the National Reactor Testing Station," Unpublished.

Sax, N. L., "Dangerous Properties of Industrial Materials," Reinhold, N. Y., 1957. 


\section{APPENDIX}

\section{RADIATION LEVELS FOR A TASK 2 GENERATOR}

During the ground handling operation each Task 2 unit is filled with approximately 4000 pounds of shield mercury. This mercury is drained at launch and would be pumped back into the unit in the case of an extended hold in the countdown. The following discussion includes listings of the dose rates from a bare unshielded source, the dose rates with the biological shield in place, and the doses during the field transfer operation.

\section{A. BARE CORE SOURCE}

Radiation dose rates were calculated for two cores at zero decay (1.7 megacuries), for one core at zero decay or two cores after one half life (0.88 megacuries), and for one core after one half life $(0.44$ megacuries). The dose rates 3 and 100 feet from the above sources are:

Dose Rates

$$
(\mathrm{r} / \mathrm{hr})
$$

(curies)

$$
\begin{aligned}
& 1.7 \times 10^{6} \\
& (2 \text { cores }) \\
& 0.88 \times 10^{6} \\
& (1 \text { core })
\end{aligned}
$$$$
0.44 \times 10^{6}
$$$$
\text { (1 core after } 1 \text { half life) }
$$

100 feet

Figure $A-1$ shows the dose rate as a function of distance from the three bare core sources, neglecting air attenuation and including selfabsorption.

\section{Shielded Generator}

Figures A-2, A-3, A-4 and Table A-1 show the dose rates at various points around a generator with the mercury shield in place. Because of the geometry of the biological shield container, the dose rates vary from point to point. At the surface of the unit, for instance, the dose rates vary from 11 to 750 milliroentgen/hour. At 1 meter from the surface of the unit, the dose rates vary from 2 to $95 \mathrm{milli}$ roentgen/hour. 


\section{Fuel Transfer}

The shipping and field loading cask is designed for a maximum dose rate of 100 milliroentgen/hour at three feet. Figure A-5 shows the total directional doses received at 3 feet during the fuel transfer operation, assuming that this operation lasts for 15 to 20 seconds. It was assumed that the mercury in the generator was level with the bottom of the collar shield. Significant directional doses would be received in specific areas around the sliding plug at the bottom of the cask, around the collar shield, and below the collar shield. Although the doses at these points would amount to as much as 5 roentgen, they are of a radial beam-type geometry and do not represent steradian doses. In addition, the actual area involved is relatively small so that these doses cannot be interpreted as total body doses. Precautions must be taken to minimize personnel doses from this source of direct radiation by limiting access of personnel during the transfer process. 


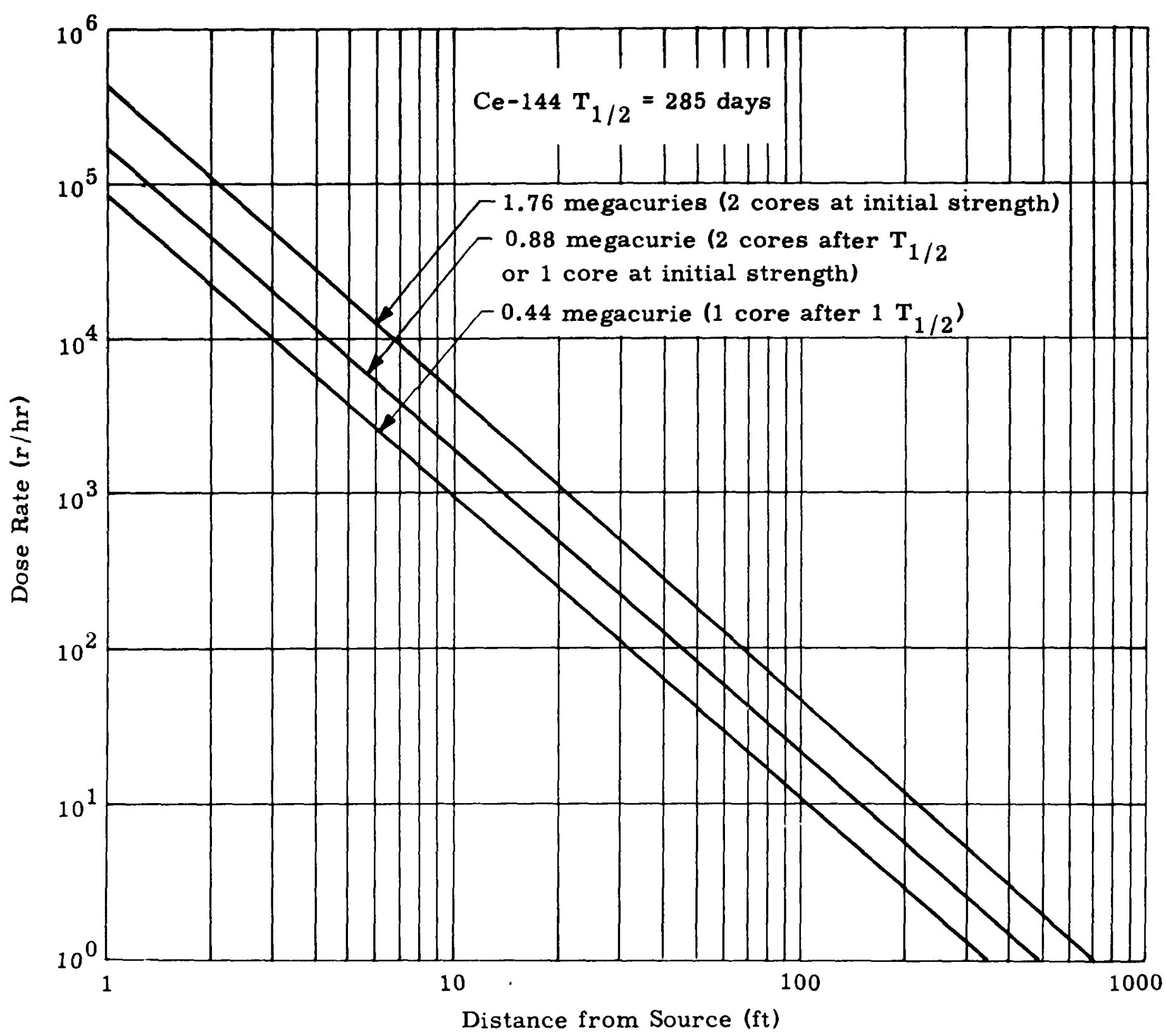

Fig. A-1. Dose Rate Versus Distance from Unshlelded Fuel Cores 


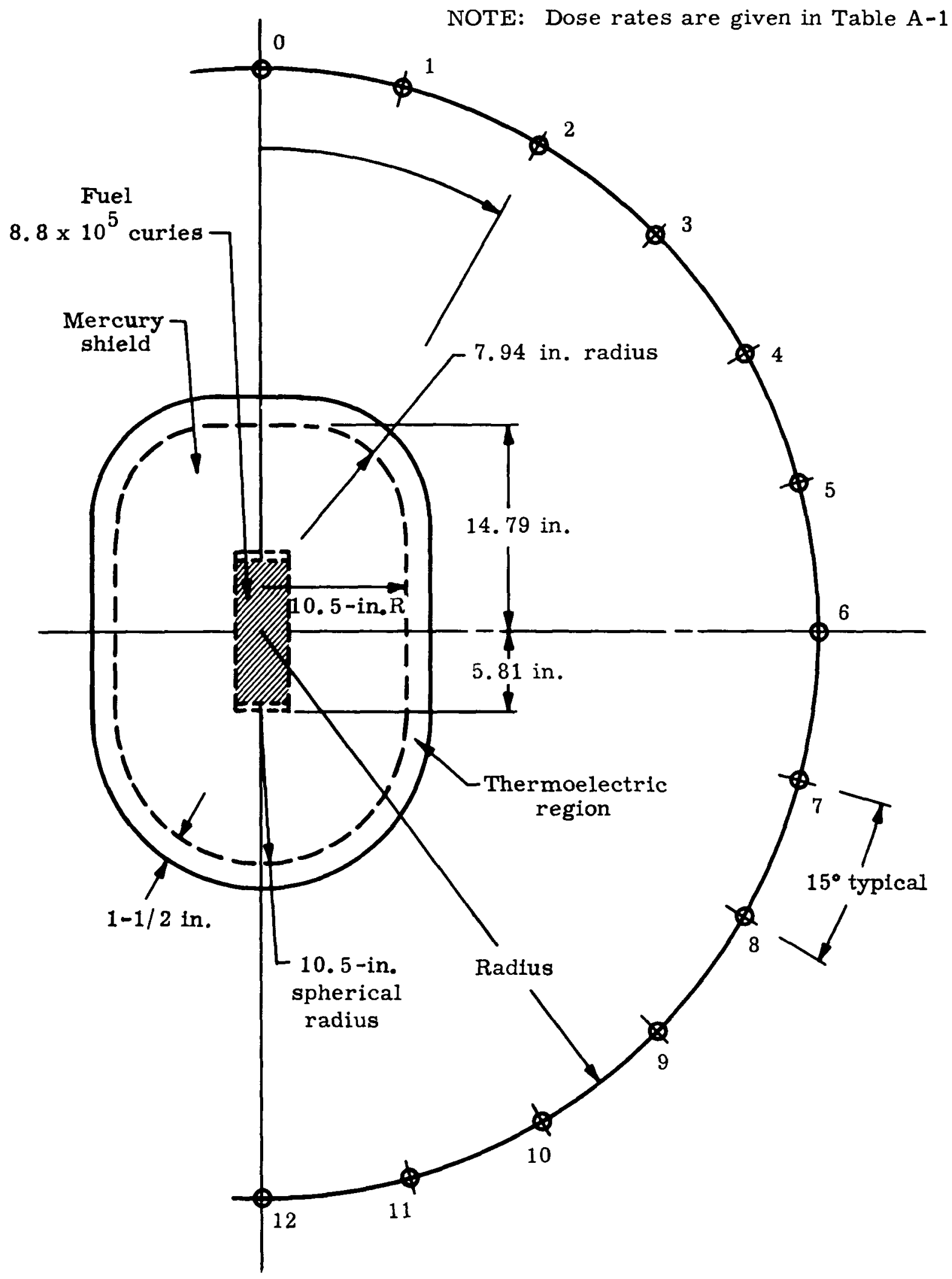

Fig. A-2. Location of Dose Points in Vertical Plane Through Generator 


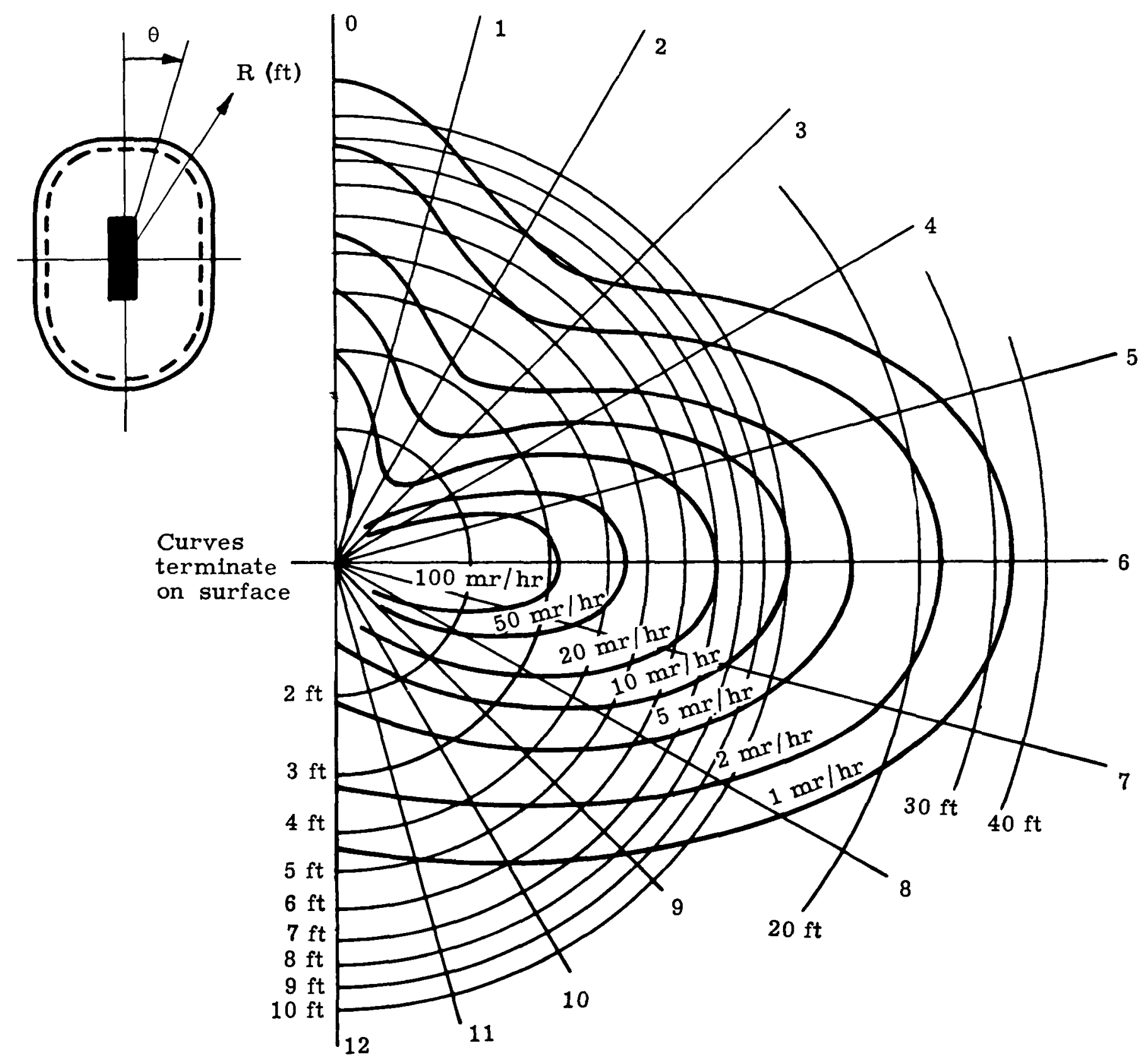

F1g. A-3. Isodose Contours in Vertical Plane Through Shielded Generator 
A -6

NOTE: All dimensions given in inches.

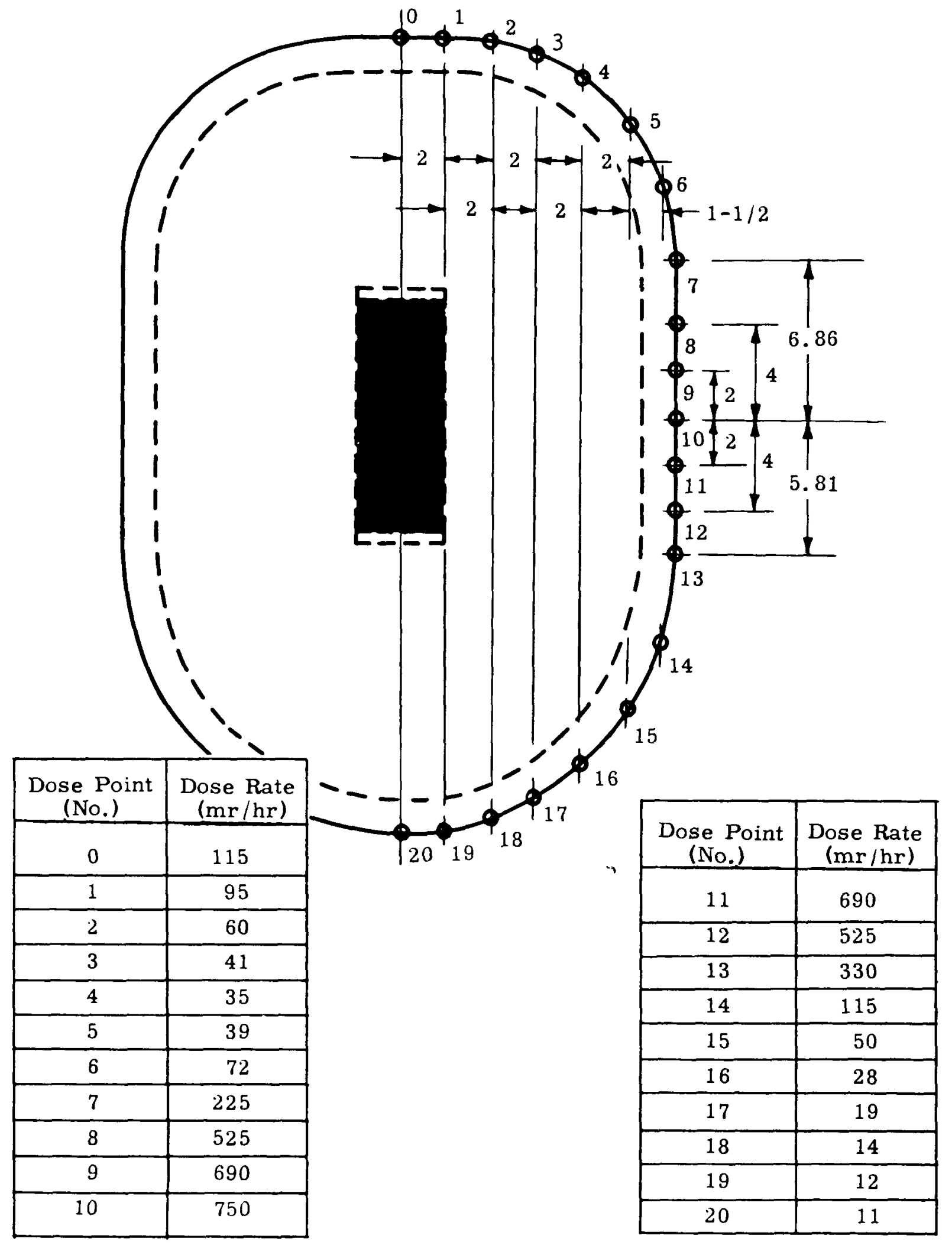

F1g. A-4. Dose Rates on Surface of Shielded Generator 
TABLE A-1

Dose Rates at Various Distances from Center of Generator with Shield Filled with Mercury

\begin{tabular}{|c|c|c|c|c|c|c|}
\hline Dose Point & 0 & 1 & 2 & 3 & 4 & 5 \\
\hline$\theta$ & $0^{\circ}$ & $15^{\circ}$ & $30^{\circ}$ & $45^{\circ}$ & $60^{\circ}$ & $75^{\circ}$ \\
\hline Radius & \multicolumn{6}{|c|}{ Dose Rate $(\mathrm{mr} / \mathrm{hr})$} \\
\hline (on surface) & 116 & 55 & 35 & 48 & 210 & 600 \\
\hline $2.5 \mathrm{ft}$ & 28 & 15 & 9 & 10 & 29 & 106 \\
\hline 1 meter & 15 & 8.8 & 5 & 5.5 & 16 & 62 \\
\hline $5.0 \mathrm{ft}$ & 6.2 & 3.6 & 2 & 2.2 & 6.7 & 26 \\
\hline $10.0 \mathrm{ft}$ & 1.5 & 0.88 & 0.5 & 0.5 & 1.7 & 6.6 \\
\hline $25.0 \mathrm{ft}$ & 0.23 & 0.14 & 0.077 & 0.083 & 0.27 & 1.1 \\
\hline $100.0 \mathrm{ft}$ & 0.014 & 0.0086 & 0.0048 & 0.0051 & 0.017 & 0.066 \\
\hline
\end{tabular}

\begin{tabular}{|c|c|c|c|c|c|c|c|}
\hline Dose Point & 6 & 7 & 8 & 9 & 10 & 11 & 12 \\
\hline$\theta$ & $90^{\circ}$ & $105^{\circ}$ & $120^{\circ}$ & $135^{\circ}$ & $150^{\circ}$ & $165^{\circ}$ & $180^{\circ}$ \\
\hline Radius & & \multicolumn{7}{|c|}{ Dose Rate (mr $/ \mathrm{hr})$} & \\
\hline (on surface) & 750 & 600 & 230 & 74 & 31 & 15 & 11 \\
\hline $2.5 \mathrm{ft}$ & 160 & 106 & 34 & 13 & 7 & 4.3 & 3.4 \\
\hline 1 meter & 95 & 62 & 19 & 7 & 4 & 2.3 & 2 \\
\hline $5.0 \mathrm{ft}$ & 42 & 26 & 8 & 2.8 & 1.5 & 0.95 & 0.77 \\
\hline $10.0 \mathrm{ft}$ & 10 & 6.6 & 2 & 0.64 & 0.34 & 0.22 & 0.18 \\
\hline $25.0 \mathrm{ft}$ & 2 & 1.1 & 0.31 & 0.10 & 0.052 & 0.035 & 0.029 \\
\hline $100.0 \mathrm{ft}$ & 0.1 & 0.066 & 0.02 & 0.006 & 0.003 & 0.002 & 0.002 \\
\hline
\end{tabular}

NOTE: Locations of dose points in relation to generator are shown in Fig. A-2. 


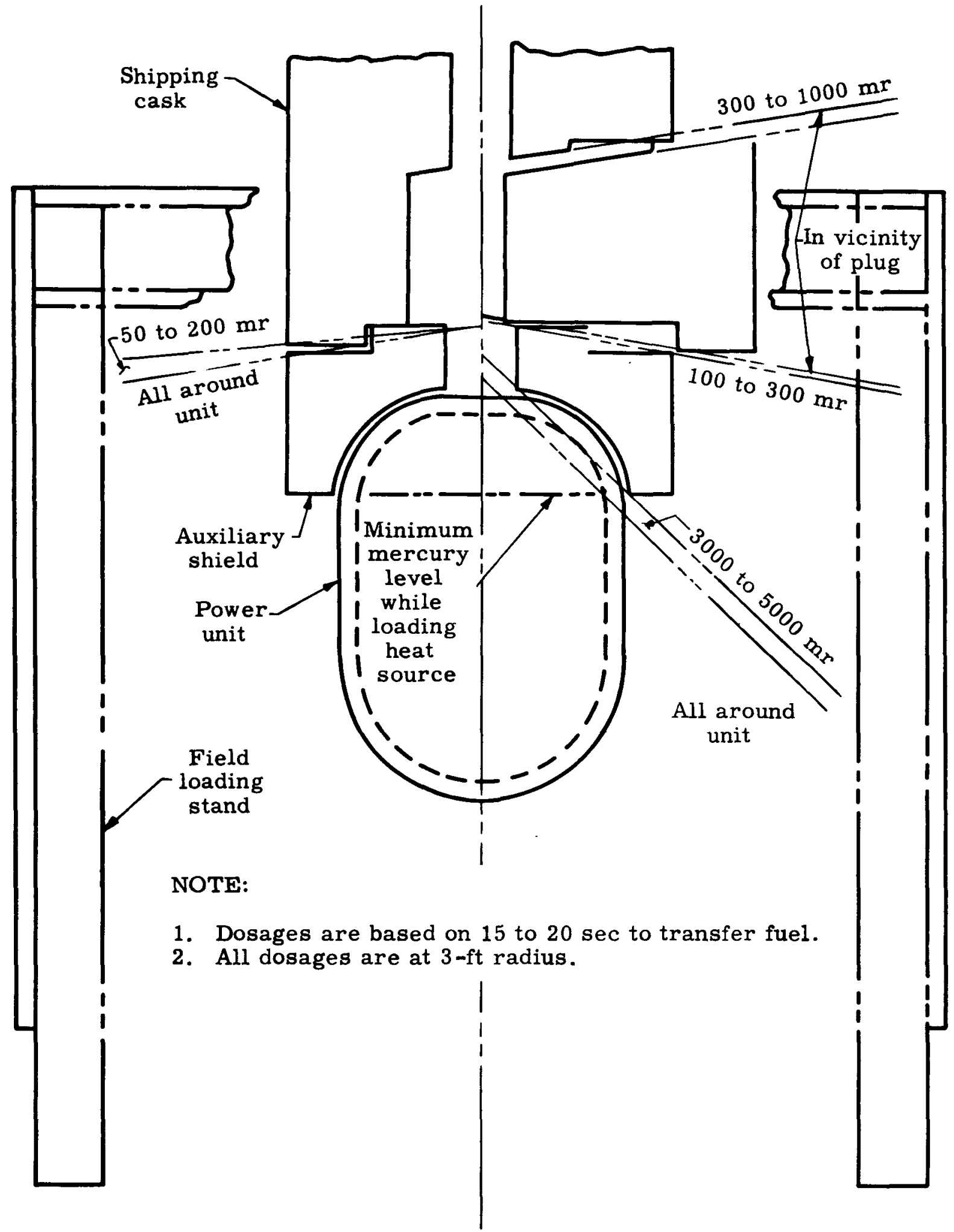

F1g. A-5. Total Doses in Exposed Areas During Fuel Transfer 